\title{
ANÁLISE BIOGEOGRÁFICA DE CORDILHEIRAS SOB PRESSÃO DA PECUÁRIA NO PANTANAL DO ABOBRAL
}

\author{
Paola Vicentini Boni \\ Universidade Federal de Mato Grosso do Sul, aluna egressa do Programa de Pós-Graduação em Geografia, \\ Três Lagoas, MS, Brasil \\ paolavicentiniboni@gmail.com
}

Mauro Henrique Soares da Silva
Universidade Federal de Mato Grosso do Sul, Professor Adjunto do curso de Geografia, Três Lagoas, MS, Brasil
mauro.soares@ufms.br

Mariane Zambone Sakuma

Universidade Estadual de Londrina, aluna do Programa de Pós-Graduação em Ciências Biológicas, Londrina, PR, Brasil. marianesakuma@gmail.com

Climbiê Ferreira Hall

Universidade Federal de Mato Grosso do Sul, Professor Adjunto do curso de Biologia, Três Lagoas, MS, Brasil climbiehall@gmail.com

\begin{abstract}
RESUMO
O Pantanal brasileiro é uma área com dinâmica biogeográfica muito específica e seu estudo se torna importante afim de compreender a paisagem. A planície pantaneira possui como atividade econômica principal a pecuária, evidenciando a importância da "cordilheira", unidade de paisagem considerada vulnerável por abrigar a fauna em períodos de cheias. Por isso, o objetivo desse trabalho é promover a compreensão das dinâmicas biogeográficas em cordilheiras no Pantanal do Abobral, uma das sub-regiões do Pantanal brasileiro. Para atender o objetivo proposto, foi realizada, primeiramente, a seleção dos alvos amostrais, sendo dois pontos de análise - uma cordilheira localizada em área preservada no interior de uma unidade de conservação (área de amortecimento da Reserva Natural do Pantanal do Rio Negro), e outra localizada fora de área protegida. Em seguida foi feito análise da vegetação, da dinâmica pedomorfológica, topográfica e das variações microclimáticas entre as cordilheiras. Os resultados obtidos deixam evidente que a cordilheira localizada em área protegida possui aspectos considerados preservados em comparação a cordilheira da área não protegida. Nota-se de maneira geral que a pecuária é influenciadora do processo de modificação da paisagem pantaneira e se faz necessário um planejamento para diminuição de prejuízos.
\end{abstract}

Palavras-chave: Análise integrada. Parque Estadual do Pantanal do Rio Negro. Paisagem.

\section{BIOGEOGRAPHIC ANALYSIS OF "CORDILHEIRAS" UNDER PRESSURE FROM LIVESTOCK RAISED IN THE PANTANAL OF ABOBRAL}

\begin{abstract}
The Brazilian Pantanal is an area with specific biogeographic dynamics and its study becomes important in order to understand the landscape. The Pantanal plain has as its main economic activity cattle raising, highlighting the importance of the "cordilheira", a landscape unit that is considered vulnerable for sheltering fauna during periods of floods. The objective of this study is to promote the understanding of biogeographic dynamics in "cordilheiras" in the Pantanal do Abobral, one of the sub-regions of the Brazilian Pantanal. To meet the proposed objective, at first, the selection of the sample targets was carried out, with two points of analysis - a" cordilheira" located in a preserved area inside a conservation unit (buffer area of the Pantanal do Rio Negro Nature Reserve), and another located outside a protected area. Then, it was made an analysis of vegetation, pedomorphological, topographic dynamics and microclimate variations between the "cordilheiras". The results obtained make it evident that the" cordilheira" located in a protected area has aspects considered preserved in comparison to the" cordilheira" of the unprotected area. It is noted, in a general way, that the livestock is influential in the process of modification of the Pantanal landscape and planning to reduce losses is necessary.
\end{abstract}

Key-words: Integrated Analysis. Pantanal do Rio Negro State Partk. Landscape.

$\begin{array}{llllll}\text { Caminhos de Geografia } \quad \text { Uberlândia-MG } & \text { v. 23, n. } 85 & \text { fev./2022 } & \text { p. 20-41 } & \text { Página } 20\end{array}$




\section{INTRODUÇÃO}

Os estudos biogeográficos são considerados um suporte para pesquisas de cunho socioambiental, que envolvem a interação entre sociedade e natureza, sendo capazes de compreender e englobar os fundamentos sobre conservação da paisagem (FURLAN et al., 2016).

O processo de análise biogeográfica da paisagem se moldou inicialmente a partir da análise da distribuição espacial da fauna e flora, segundo Martonne (1932), e posteriormente Humbold vinculou o solo, clima e vegetação aos estudos da Biogeografia. Complementando, Ratzel propôs a Biogeografia Universal que buscava conectar os aspectos naturais aos sociais, no entanto, nesse período não foi aceito (ALBUQUERQUE et al., 2004).

Apesar dos estudos biogeográficos passarem por evolução, foi difundido somente a partir da necessidade pela preservação do meio natural através da criação de práticas de planejamento da paisagem associadas as mudanças naturais sob influência antrópica, que causa um processo de adaptação do meio (FIGUEIRÓ, 2015).

Como visto, a biogeografia está relacionada à paisagem, sobre isso Bertrand $(1971 ; 2004)$ define a paisagem como o resultado de uma combinação dinâmica de elementos geográficos, biológicos e antrópicos, sempre em evolução. Em complemento Passos (1988) e Figueiró (2015) acreditam que a paisagem é considerada o resultado de uma complexa história evolutiva dos elementos como seres vivos, clima, hidrografia, solo e relevo em diferentes escalas, em constante modificação.

Por isso, atualmente, os estudos biogeográficos não estão associados a interpretação e espacialização da distribuição da fauna e flora, mas buscam lidar com diminuição da biota, levando em consideração o sistema de desenvolvimento econômico atual, capitalismo, que insere espécies exóticas, justificado pelo valor econômico que tais espécies proporcionam, como por exemplo na pecuária, com a inclusão de gramíneas segundo Lima (2003) e Figueró (2015).

É evidente que os estudos biogeográficos provocam a percepção sobre o dinamismo de uma paisagem, Albuquerque et al. (2004) demonstra a necessidade na associação teórica com o planejamento ambiental, baseando-se em cartografia, estatística, modelagem, análise, interpretação, comparação para compreender a distribuição dos elementos e como essa interação provoca modificações em cada unidade de paisagem, baseando-se na história e cultura.

O Pantanal brasileiro é uma área com características paisagísticas complexas, como exposto nas perspectivas dos estudos biogeográficos e paisagístico. A planície pantaneira, área de estudo do presente trabalho, é considerada Reserva da Biosfera Mundial pela Comissão Internacional do Programa MaB (Man and the Biosphere) (UNESCO, 2000) devido sua importância mundial para a conservação

O Pantanal está localizado entre as coordenadas $58^{\circ} 35^{\prime} \mathrm{W}$; $15^{\circ} 28^{\prime} \mathrm{S}$ e $54^{\circ} 43^{\prime} \mathrm{W} ; 22^{\circ} 12^{\prime} \mathrm{S}$, com área de aproximadamente $600.000 \mathrm{~km}^{2}$, se estende por países como o Brasil, Bolívia e Paraguai. No Estado de Mato Grosso do Sul, sua área total é de aproximadamente $135.000 \mathrm{~km}^{2} \mathrm{com}$ altitudes variando de $80 \mathrm{~m}$ a $190 \mathrm{~m}$ (ASSINE, 2003; ASSINE e SOARES, 2004). É considerado uma bacia sedimentar, localizada no interior da Bacia do Alto Paraguai (BAP) de característica deprimida, plana e sazonalmente inundável, cuja rede de drenagem é comandada pelo rio Paraguai (FRANCO e PINHEIRO, 1982).

Devido a extensa área, há inúmeras propostas de compartimentação do Pantanal, como a de Sánchez (1977), Franco e Pinheiro (1982), Adámoli (1982), Alvarenga et al. (1984), Silva e Abdon (1998) e Mioto, Paranhos Filho e Albrez (2012). Neste trabalho optou-se pela proposta de Silva e Abdon (1998), por ele considerar o Abobral como uma região e utiliza os aspectos de inundação, relevo, vegetação e solo que são aspectos fundamentais para análise biogeográfica proposta na pesquisa.

A sub-região do Abobral (Figura 1) está localizada ao sul da planície pantaneira do Rio Abobral e é composta por diferentes unidades de paisagem que desempenham funções importantes para a biodiversidade local, podem-se citar as cordilheiras, objeto de estudo deste trabalho, além dos capões, formações campestres, florestas ripárias e outras (FRANCO e PINHEIRO, 1982). 
Figura 1- Localização do Pantanal do Abobral, Mato Grosso do Sul, Brasil.

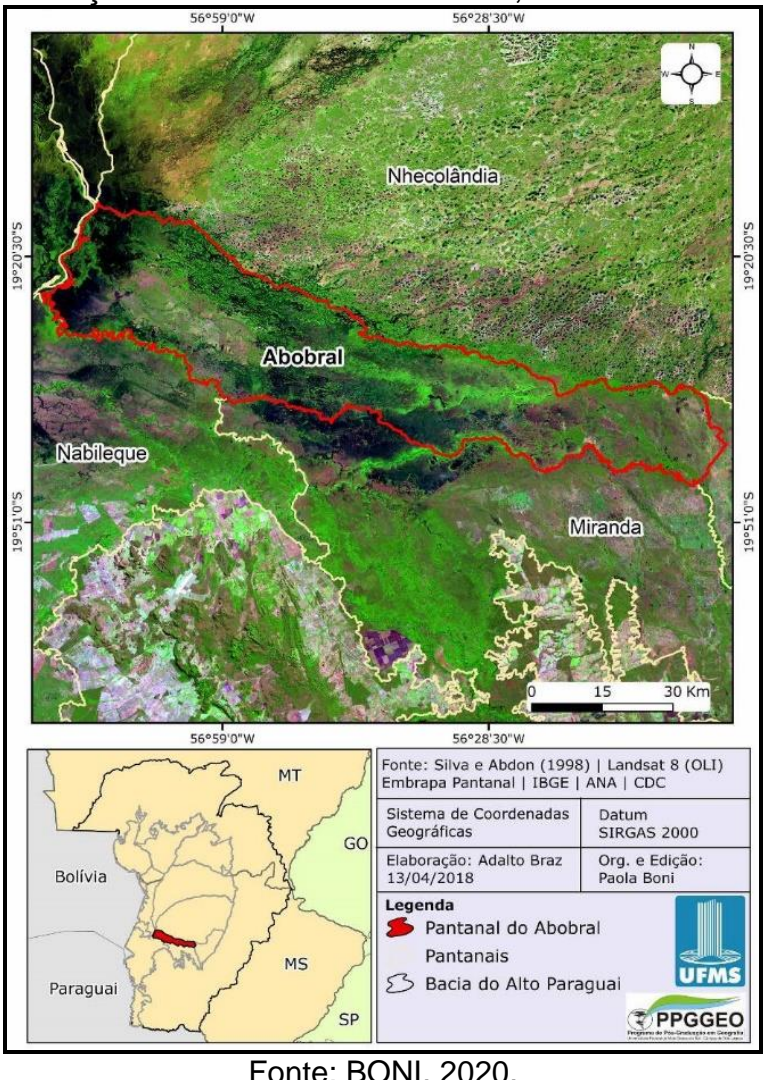

O termo cordilheira é utilizado regionalmente para denominar uma unidade de paisagem caracterizada como cordão de vegetação com altura variando de 2 a 3 metros acima da área de pastagem que circunda a unidade, constituem área quase nunca alagadas, sendo atingidas somente em cheias excepcionais, utilizadas também como abrigo do gado nos períodos de inundação. $O$ solo que compõe essa unidade, são Neossolos Quartzarênico e Espodolossolos, com vegetação predominante de Cerrado (FRANCO e PINHEIRO, 1982). O Pantanal do Abobral possui áreas aptas para a atividade de pecuária extensiva. No entanto Cunha, Pott e Gonçalves (1985) aponta algumas observações em relação a expansão dessa atividade: constatou-se que a pecuária se limitava apenas a áreas de pastagens nativas; porém, com o acontecimento de cheias excepcionais, a partir de 1985, a criação do gado no Abobral passou a diminuir, mas voltou a crescer, conforme os pecuaristas passaram a utilizar áreas florestadas não inundáveis, conhecidas regionalmente como cordilheiras e os capões, como áreas de pastagens. Na maioria das vezes a vegetação nativa era suprimida, para "facilitar" a expansão da pecuária (RAVAGLIA et al., 2010).

Tendo a pecuária como principal fonte econômica do Pantanal, com estratégia de uso das cordilheiras como abrigo, pelo gado, e as demais unidades de paisagem sofrendo cada vez mais pressões antrópicas, autores como Silva e Abdon (1998), Padovani, Cruz e Padovani (2004), Ravaglia et al. (2010), Silva (2012), Sepúlveda (2016), Andrade (2017) e Silva, Gradella e Decco (2017) concordam que esta é a atividade de maior impacto em relação as influências de modificação ou de alteração da paisagem pantaneira.

Andrade (2017) constatou que os dados apresentados evidenciam a diminuição da vegetação nativa (arbórea) e de corpos hídricos e em contrapartida, constatou o aumento dos campos e pastagens. Desse modo, reforça-se a premissa de que a pecuária exerce influência sobre as unidades de paisagem de caráter natural (SILVA e ABDON, 1998; TOMAS et al., 2009). Por isso, reafirma-se a relevância dos estudos que avaliem a atuação dos impactos e da pressão antrópica na paisagem do Pantanal, como justificativa para esta pesquisa.

Em relação à redução das áreas com vegetação nativa arbórea (cordilheiras e capões), em consequência do desmatamento, deve-se pensar que os impactos negativos sobre as unidades de paisagem são maiores, a exemplo da degradação do solo causada pelo pisoteio excessivo do gado,

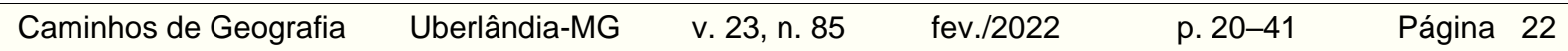


influenciando na compactação do solo e favorecendo o processo de erosão; por fim, provocando alterações significativas nas camadas superficiais do solo. Percebe-se aqui a existência de uma relação intrínseca que também afeta os aspectos biogeográficos das cordilheiras (CUNHA, POTT e GONÇALVES, 1985; RAVAGLIA et al., 2010; SILVA, 2012).

Justifica-se a escolha dessa unidade da paisagem (cordilheira), devido à sua função de servir como abrigo para a fauna durante os períodos de cheias e, consequentemente, utilizada pelos fazendeiros como refúgio para o gado. Há, portanto, um potencial para alterações de sua dinâmica natural, do ponto de vista biogeográfico, porquanto as cordilheiras são unidades mais vulneráveis, pelos motivos mencionados, afetadas diretamente pela ação antrópica.

Por esta razão, torna-se necessário avaliar os possíveis problemas causados pela pecuária e a sua relação com a diminuição de áreas de vegetação nativa arbórea. Assim, é possível compreender os impactos causados na dinâmica ambiental dessa unidade de paisagem, tendo como principal variável o solo, o clima, a vegetação e a topografia.

Esta pesquisa tem como objetivo geral compreender a dinâmica da unidade de paisagem, cordilheira, sob influência da pecuária no Pantanal do Abobral. Em termos específicos, a pesquisa se propõe analisar as dinâmicas pedológica, topográfica, climáticas e biogeográfica em áreas de cordilheiras, sob diferentes condições de pressão pelas ações antrópicas visando estabelecer uma associação entre os elementos que compõem a estrutura da paisagem e a maneira como a pecuária atua sobre tais unidades.

\section{METODOLOGIA}

Para o alcance dos objetivos propostos neste trabalho, foram elaboradas quatro etapas.

\section{Etapa 1 - Seleção dos alvos amostrais}

$\mathrm{Na}$ perspectiva do desenvolvimento da pesquisa sobre análise de unidades de paisagem com cunho biogeográfico, adotou-se unidades amostrais de pesquisa constituintes do Pantanal do Abobral, o qual se localiza na parte sul do Pantanal Sul- Mato-grossense.

Levando em conta que as unidades da paisagem presentes no Pantanal do Abobral possuem relações integradas, ou seja, suas variáveis estão inter-relacionadas, neste trabalho as áreas tomadas para tal análise, foram as cordilheiras de dois quadrantes amostrais, sendo um quadrante localizado em propriedade rural, próximo a Estrada Parque - rota turística de importante fluxo econômico da região - que em anos anteriores baseava-se estritamente na pecuária, mas que atualmente realiza atividades concomitantemente voltadas para o ecoturismo e a pecuária (em menor escala); e outro quadrante localizado na zona de amortecimento do Parque Estadual do Pantanal do Rio Negro (PEPRN), área pertencente à Unidade de Conservação e, portanto, integrada à um sistema específico de legislação em prol da conservação ambiental. Tais quadrantes foram denominados nesta pesquisa respectivamente de quadrantes 2 e 1.

A criação do PEPRN tem como objetivo principal preservar amostras do ecossistema do Pantanal (flora e fauna) e o regime hidrológico, garantindo a sazonalidade e a valorização da paisagem e cultura da região. Essa área destinada à Unidade de Conservação (UC) também deve ser estimulada para pesquisas cientificas, para a educação ambiental, a recreação e para o turismo (SEMAC, 2008).

Para atender os propósitos do plano de manejo, o PEPRN foi dividido em seis zonas internas como parte dos requisitos obrigatórios para criação de uma UC, dentre elas a zona de amortecimento responsável por restringir as atividades humanas por meio de normas com propósitos específicos, a fim de minimizar possíveis impactos negativos à maior parte das categorias de unidades de conservação (SEMAC, 2008).

A escolha de ambas áreas para esse trabalho foi intencional e com o objetivo de compreender as diferenciações ou semelhanças em áreas com duas dinâmicas ambientais diferentes, sendo uma considerada unidade de conservação, respaldada por um plano de manejo e a outra sem nenhum direcionamento de uso e ocupação. O tamanho dos quadrantes teve como critério a representação de quantidade significativa de unidades de paisagem específicas dessa região do Pantanal de acordo com Sepúlveda (2016), Andrade (2017) e Silva Gradella e Decco (2017), sobretudo no que se refere à presença de Cordilheiras. Já as cordilheiras amostrais descritas na presente pesquisa foram 
escolhidas aleatoriamente, utilizando apenas o critério de facilidade de acesso dentro de cada quadrante.

\section{Etapa 2 - Análise da vegetação das cordilheiras}

A análise biogeográfica foi baseada na observação da vegetação, através dos procedimentos conhecidos como pirâmides de vegetação propostos por Bertrand (1968). Esses procedimentos possibilitaram uma representação gráfica da estrutura vertical de uma formação vegetal com ênfase em dados coletados.

A metodologia procedeu com a realização de três parcelas de 10x10 metros, localizadas no sentido borda-centro-borda, em cada uma das áreas amostrais selecionadas (Cordilheira em área de amortecimento de UC - Figura 2, e cordilheira em área não protegida - Figura 3), adaptado de Felfili, Carvalho e Haidar (2005), e busca compreender os aspectos fitogeográficos dos diferentes ambientes da formação vegetal (ANDRADE, 2017).

Figura 2 - Localização das parcelas na cordilheira do quadrante 1 (Zona de Amortecimento da UC), Pantanal do Abobral, MS.

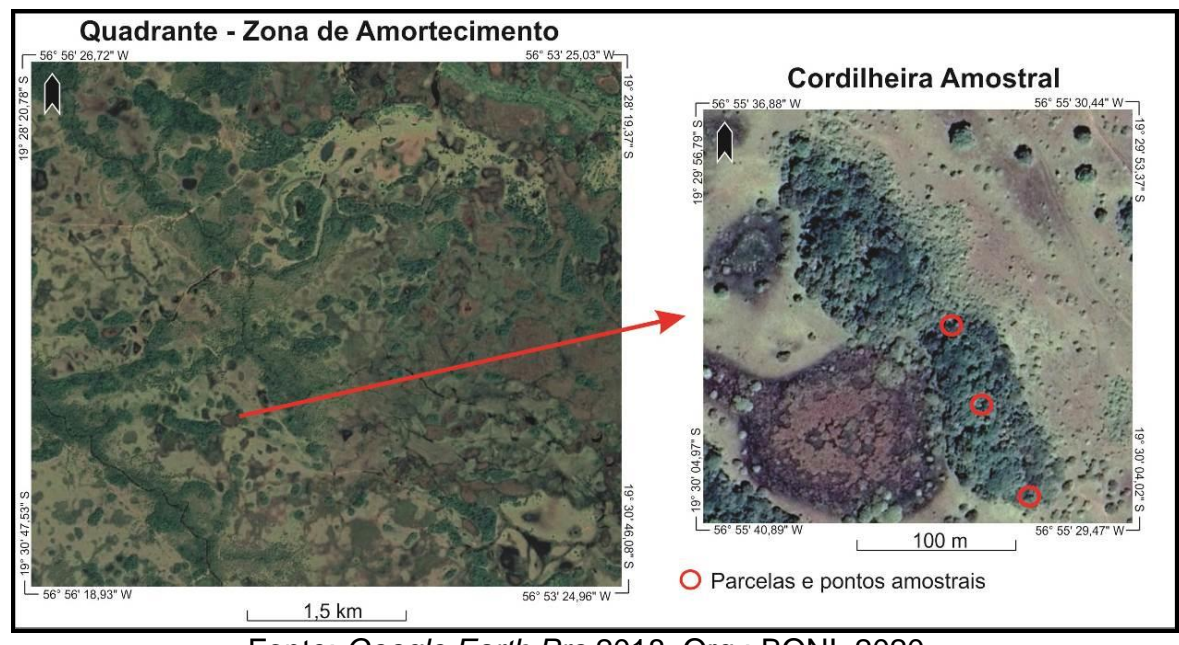

Fonte: Google Earth Pro 2018. Org.: BONI, 2020.

Figura 3 - Localização das parcelas na cordilheira do quadrante 2 (área não protegida), Pantanal do Abobral, MS.

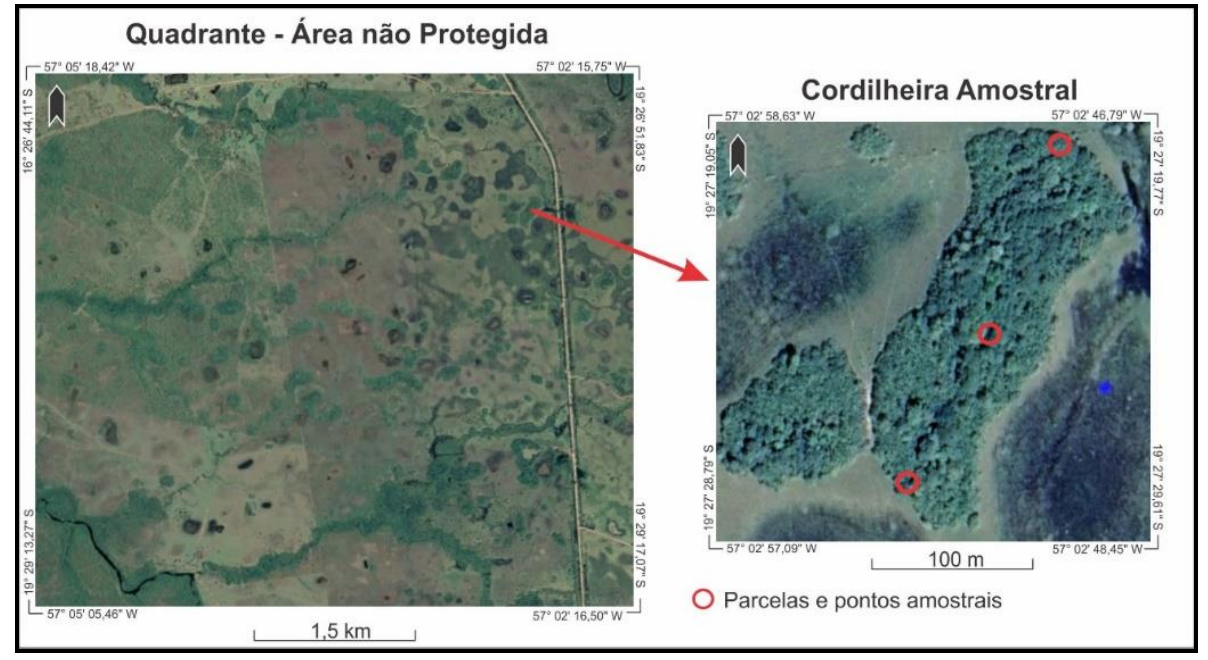

Fonte: Google Earth Pro 2018 . Org.: BONI, 2020.

Durante as análises das parcelas, foi realizado o preenchimento de fichas biogeográficas adaptadas por Passos (1988) a partir do modelo proposto por Bertrand (1968), para aplicação em pirâmides de vegetação, com parâmetros de sociabilidade e de abundância-dominância (Quadro 1). Reunindo

$\begin{array}{llllll}\text { Caminhos de Geografia } & \text { Uberlândia-MG } & \text { v. 23, n. } 85 & \text { fev./2022 } & \text { p. 20-41 } & \text { Página } 24\end{array}$


estrato e altura, os dados possibilitam categorizar os estratos em graus que demonstram 0 recobrimento de vegetação, segundo Braun-Blanquet (1979), Passos (1988) e Sakuma e Silva (2017).

Quadro1 - Critérios para a classificação da abundância-dominância e da sociabilidade.

\begin{tabular}{|c|c|c|}
\hline \multicolumn{2}{|c|}{ Abundância-Dominância } & Sociabilidade \\
\hline 5 & Cobrindo entre 75 a $100 \%$. & População contínua; manchas densas. \\
\hline 4 & Cobrindo entre 50 a $75 \%$. & $\begin{array}{c}\text { Crescimento em pequenas colônias; manchas } \\
\text { densas pouco extensas, }\end{array}$ \\
\hline 3 & Cobrindo entre 25 a $50 \%$. & Crescimento em grupos. \\
\hline 2 & Cobrindo entre 10 a $25 \%$. & Agrupados em 2 ou 3. \\
\hline 1 & $\begin{array}{c}\text { Planta abundante, porém, com valor de } \\
\text { cobertura baixo, não superando } 10 \% .\end{array}$ & Planta rara ou isolada. \\
\hline+ & Alguns raros exemplares. & isolado. \\
\hline
\end{tabular}

Fonte: Braun-Blanquet (1979) e Passos (2003).

Andrade (2017) explica que os aspectos geográficos são elementos que interferem, de forma direta ou indireta, na vegetação, com enfoque ambiental, como a dinâmica da cobertura pedológica; caracterização climática; vestígios de fauna e as alterações antrópicas.

Desse modo, o método de Pirâmides de Vegetação é um caminho para análise ambiental, que permite não apenas compreender a estrutura vertical da vegetação, mas também as relações biogeográficas. Esta, por si, possibilita compreender a cobertura vegetal como um componente do complexo paisagístico (BERTRAND, 1968; SILVA, 2016 e ANDRADE, 2017). Para a elaboração das pirâmides, utilizou-se o software Corel Draw Graphics Suite X7.

Andrade (2017) explica a composição da pirâmide de vegetação da seguinte maneira:

\begin{abstract}
$\mathrm{Na}$ pirâmide, horizontalmente representa-se os padrões de abundância-dominância, enquanto que no sentido vertical indica-se a sociabilidade. Assim, a extensão horizontal dos estratos em relação ao eixo central, para ambos os lados, seguiu os valores do índice de recobrimento (abundância-dominância), sendo $(+)=0,5 \mathrm{~cm}, 1=1 \mathrm{~cm}, 2=$ $2 \mathrm{~cm}, 3=3 \mathrm{~cm}, 4=4 \mathrm{~cm}$ e $5=5 \mathrm{~cm}$. Já a espessura dos estratos foi determinada com base no índice de sociabilidade verificado em campo, sendo $(+)=0,5 \mathrm{~cm}, 1=1 \mathrm{~cm}, 2=$ $2 \mathrm{~cm}, 3=3 \mathrm{~cm}, 4=4 \mathrm{~cm}$ e $5=5 \mathrm{~cm}$. A dinâmica de cada porte foi representada por símbolos, onde $(\leftarrow \rightarrow)$ indica progressão, $(\rightarrow \leftarrow)$ regressão e $(=)$ equilíbrio, mediante os dados coletados nas fichas biogeográficas. $E$ na base da pirâmide encontra-se informações sobre serrapilheira (baixa $-0,1 \mathrm{~cm}$, média $0,3 \mathrm{~cm}$ e alta $0,5 \mathrm{~cm}$ ) e abaixo dessas informações, indica-se o tipo de solo da formação (ANDRADE, 2017, p. 70).
\end{abstract}

A metodologia de pirâmide de vegetação é eficaz pois permite uma análise ambiental ampla e integrada, capaz de entender a estrutura vertical da cobertura vegetal, as relações biogeográficas entre os elementos da unidade de paisagem estudada.

\title{
Etapa 3 - Análise da dinâmica pedomorfológica e topográfica das cordilheiras
}

Inicialmente foi realizada a caracterização topográfica de cada cordilheira amostral. Deste modo, a análise da topografia foi realizada no interior das cordilheiras amostrais, de $10 \mathrm{em} 10$ metros de distância para cada ponto de coleta. Através dessa distância é possível identificar os pontos de maior e de menor elevação.

A topossequência longitudinal foi realizada de sentido leste a oeste e três topossequências transversais para elaborar o modelo tridimensional em 3D, com auxílio do software Global Mapper, que possibilitou a compreensão do formato da cordilheira juntamente com os dados de topografia.

Essa etapa da pesquisa direcionou-se, ainda, para coleta de amostras de solos e para análise da topografia das cordilheiras estudadas. Para a obtenção de amostras da camada pedológica optou-se pelo método da topossequência, e utilizou-se do trado do tipo holandês, para perfuração de pontos amostrais, em um transecto ao longo das cordilheiras, sondo que cada ponto foi estabelecido de acordo com as configurações de mudanças de cobertura de superfície além da topografia. Tais pontos foram denominados T1, T2 e T3, na cordilheira localizada na Zona de Amortecimento do PEPRN, além do ponto T4 na cordilheira em área não protegida; sendo que nesta última, por apresentar dificuldade de perfuração da camada pedológica com o trado, realizou-se também a

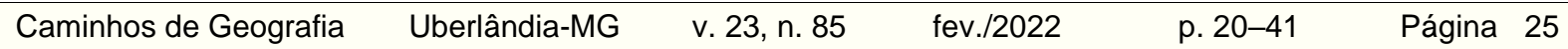


aberturas de trincheiras1, denominadas T5 e T6, com profundidade variável, de modo a concluir as perfurações necessárias para a investigação pedológicas em transecto.

Após a coleta em campo, iniciou-se as preparações para a análise granulométrica em laboratório. As amostras foram colocadas para secagem de forma natural através do método TFSA (Terra Fina Seca ao Ar), sugerido por Almeida et al. (2012) através de estudos realizados pela Embrapa. Em seguida, iniciou-se a análise granulométrica, metodologia utilizada para definir a dimensão dos sedimentos (Tabela 2), quanto ao volume e peso (SUGUIO, 1973; DIAS, 2004).

Tabela 2 - Classificação granulométrica das partículas.

\begin{tabular}{l|l}
\multicolumn{1}{c|}{ Diâmetro $(\mathrm{mm})$} & \multicolumn{1}{c}{ Denominação } \\
\hline $2,00-1,00$ & Areia muito grossa \\
\hline $1,00-0,50$ & Areia grossa \\
\hline $0,50-0,21$ & Areia média \\
\hline $0,21-0,10$ & Areia fina \\
\hline $0,10-0,05$ & Areia muito fina \\
\hline $0,05-0,002$ & Silte \\
\hline$<0,002$ & Argila \\
\hline
\end{tabular}

Fonte: Almeida et al. (2012).

A partir da análise em campo e em laboratório buscou-se compreender os processos pedogenéticos, a migração de nutrientes e matéria orgânica em todo perfil. Além disso, propondo uma análise comparativa, a fim de compreender a influência da pecuária sobre a camada pedológica das áreas de estudo, realizou-se análise química de algumas profundidades (Tabela 3) no Laboratório de Fertilidade do solo da Universidade Estadual Paulista Júlio de Mesquita Filho (UNESP). Foram analisados $\mathrm{pH}$, matéria orgânica, fósforo, magnésio, cálcio, $\mathrm{H}+\mathrm{Al}$ (Hidrogênio + Alumínio) e CTC (Capacidade de troca de cátions). A escolha das amostras analisadas em laboratório foi baseada nas observações em campo2, por exemplo: mudança de coloração, presença de agregados, carapaças, raízes, manchas e veios.

Tabela 3 - Profundidades com análise química.

\begin{tabular}{c|c|c|c|c|c|c}
\hline $\begin{array}{c}\text { Pontos de } \\
\text { coleta }\end{array}$ & T1 & T2 & T3 & T4 & T5 & T6 \\
\hline \multirow{4}{*}{ Profundidades } & $0-20$ & $0-20$ & $0-10$ & $0-10$ & $0-30$ & $0-5$ \\
\cline { 2 - 7 } & $20-50$ & $60-70$ & $30-60$ & $40-60$ & $30-60$ & $5-75$ \\
\cline { 2 - 7 } & $70-100$ & $110-130$ & - & $100-110$ & $85-125$ & $75-90$ \\
\cline { 2 - 7 } & - & $180-200$ & - & - & - & - \\
\hline
\end{tabular}

Fonte: Autora (2020)

\section{Etapa 4 - Análise das variações microclimáticas entre as cordilheiras}

As coletas de dados foram divididas em dois momentos, sendo no Quadrante 1 - Zona de amortecimento, em 18 e 19 de setembro de 2019; no Quadrante 2 - área não protegida, em 29 e 30 de dezembro de 2019. Em ambos os períodos a atmosfera apresentou-se estável, com baixa nebulosidade e velocidade dos ventos, mostrando inocorrências quanto à atuação de fenômenos perturbadores da atmosfera.

1 A abertura de trincheiras, somente em dois pontos de análise, justifica-se pela dificuldade da retirada de material através do trado, devido ao baixo grau de umidade, fazendo com que o material estivesse solto.

20 ponto T2 detém maiores análises devido à tradagem com maior profundidade; já no T3 foi analisado somente duas amostras devido à dificuldade em atingir maiores profundidades ante a presença rochosa.

$\begin{array}{llllll}\text { Caminhos de Geografia } & \text { Uberlândia-MG } & \text { v. 23, n. } 85 & \text { fev./2022 } & \text { p. 20-41 } & \text { Página } 26\end{array}$


Para o monitoramento dos estados do tempo meteorológico, em ambas áreas e compreensão das influências de sua configuração paisagística nas variações horárias de temperatura e umidade, foram instalados dois sensores Data Loggers HOBO U23, um localizado no centro das cordilheiras e outro cerca de $10 \mathrm{~m}$ fora da borda, em campo aberto. O registro possibilita a obtenção de dados de temperatura e umidade, com intervalo de uma hora tendo como base a metodologia adaptada de (SOKOLOWSKI et al., 2015) e (SILVA, GRADELLA e DECCO2017), durante 24h, iniciando e terminando às $13 \mathrm{~h}$. Para isso, ocorreu a programação dos sensores para captação de informações térmicas através do software HOBOWARE $\AA$.

Após a obtenção dos dados de temperatura e umidade foram construídos gráficos no Microsoft巴 Office Excel para comparação das cordilheiras, conforme a localização dos sensores.

\section{RESULTADOS E DISCUSSÕES}

As pastagens, de acordo com o IBGE $(2006 ; 2017)$, nos municípios de Corumbá e Aquidauana são em maiores quantidades naturais. No entanto, quando se trata da conservação dos campos, os dados, do próprio IBGE, revelam que de 2006 para 2017, ocorreu um aumento de pastagem em más condições em ambos os municípios. Deixando evidente, que os campos cobertos por pastagens, sejam naturais ou artificiais, necessitam de manutenção e de legislação para a proteção.

Sabe-se que a presença tão marcante da pastagem é justificada pela pecuária, considerada de importância cultural e econômica para região. No entanto, notou-se que a quantidade de animais provenientes da pecuária em determinadas áreas pode causar prejuízos às unidades de paisagem do Pantanal do Abobral. Por isso, são necessárias medidas de fiscalização sobre a permissão da atuação da pecuária em áreas no interior do PEPRN.

Além disso, deve-se levar em conta que o fato da infraestrutura oferecida na região da área não protegida, através da Estrada Parque, proporcionou maior aproximação com as áreas urbanas e, dessa forma, o "desenvolvimento econômico" facilitado. Diferentemente da região da Zona de Amortecimento, na qual a exploração dos recursos naturais e a modificação das unidades de paisagem são menos evidentes.

O desenvolvimento da infraestrutura junto com a expansão da pecuária deixa marcas na paisagem, prejudicando a dinâmica natural do Pantanal. Por exemplo, os resultados referentes à topografia de ambas as cordilheiras, mostram que a cordilheira da Zona de Amortecimento possui aspectos semelhantes ao das bibliografias já citadas anteriormente, enquanto que a localizada próxima à área não protegida possui maiores "irregularidades" topográficas, chegando a medidas negativas; ocasionadas pela erosão nos períodos de inundação e agravada pela presença dos bovinos. É necessário enfatizar que ambas unidades de paisagem apresentaram indícios de atividade bovina.

Assim, com base nos levantamentos e análises realizadas por meio dos procedimentos adotados para essa pesquisa, observou-se que as parcelas analisadas possuem diferenças e aspectos relevantes quanto à estrutura de vegetação de cada unidade amostral. No entanto, foram identificados elementos de antropização em ambas as áreas estudadas. Por exemplo, na cordilheira localizada em área de amortecimento do PEPRN encontrou-se indícios de áreas antropizadas com presença de fezes de gado, espécies arbóreas exóticas de possível introdução no sistema por processos antrópicos, tais como limoeiro, goiabeira, e ainda um túmulo3, sendo que na área não protegida, como esperado, notou-se a presença do gado, por meio da visualização de pegadas, caminhos de pisoteio e vezes.

Sobre a dinâmica que envolve a disposição da vegetação nota-se que na pirâmide de vegetação referente à parcela 1 (Figura 4), na área de amortecimento de UC, a cobertura vegetal é predominantemente composta pelo porte arbóreo (cobertura de 25 a 50\%); assim como porte arbustivo (cobrindo menos de 10\%). Ambos são encontrados de forma isolada e em regressão. $\mathrm{Na}$ parcela 2, o porte arbóreo é predominante quanto à abundância e dominância (cobrindo $75 \%$ a 100\%). Este é encontrado como manchas densas contínuas, explicadas pela presença de Attalea phalerata, conhecido popularmente como acuri. Essa proeminente abundância-dominância,

3 Essa região do Pantanal é historicamente considerada uma área de pastagem de população migratória, e, portanto, era comum utilizar a área como acampamento e em alguns casos como cemitérios.

$\begin{array}{llllll}\text { Caminhos de Geografia } & \text { Uberlândia-MG } & \text { v. 23, n. } 85 & \text { fev./2022 } & \text { p. 20-41 } & \text { Página } 27\end{array}$


associada à falta de diversidade de espécies, apresenta monodominância na parcela em progressão, com poucos exemplares de espécies arbóreas e ausência dos demais estratos, evidenciando um desequilíbrio que, por sua vez sugere uma regressão de todos os estratos da parcela. Estes aspectos não são comuns em cordilheiras, por exemplo os acuris estão sempre localizados nas bordas das cordillheiras, devido à necessidade da iluminação e por sua fácil adaptação com a água (NEGRELLI, 2013). No entanto, nota-se que a área central da cordilheira sofreu mudanças marcada pela falta de vegetação de grande porte, quando comparado com demais cordilheiras descritas na bibliografia já apresentada. Na parcela 3, o arbóreo cobre entre $25 \%$ a $50 \%$ da parcela analisada e os indivíduos são vistos como raros, bem como o porte arbustivo, diferentemente do porte herbáceo, que cobre menos de $10 \%$. Os três portes são vistos como plantas raras ou isoladas.

Figura 4 - Pirâmides de vegetação das parcelas 1, 2 e 3 referentes à Zona de Amortecimento do PEPRN e da área não protegida.

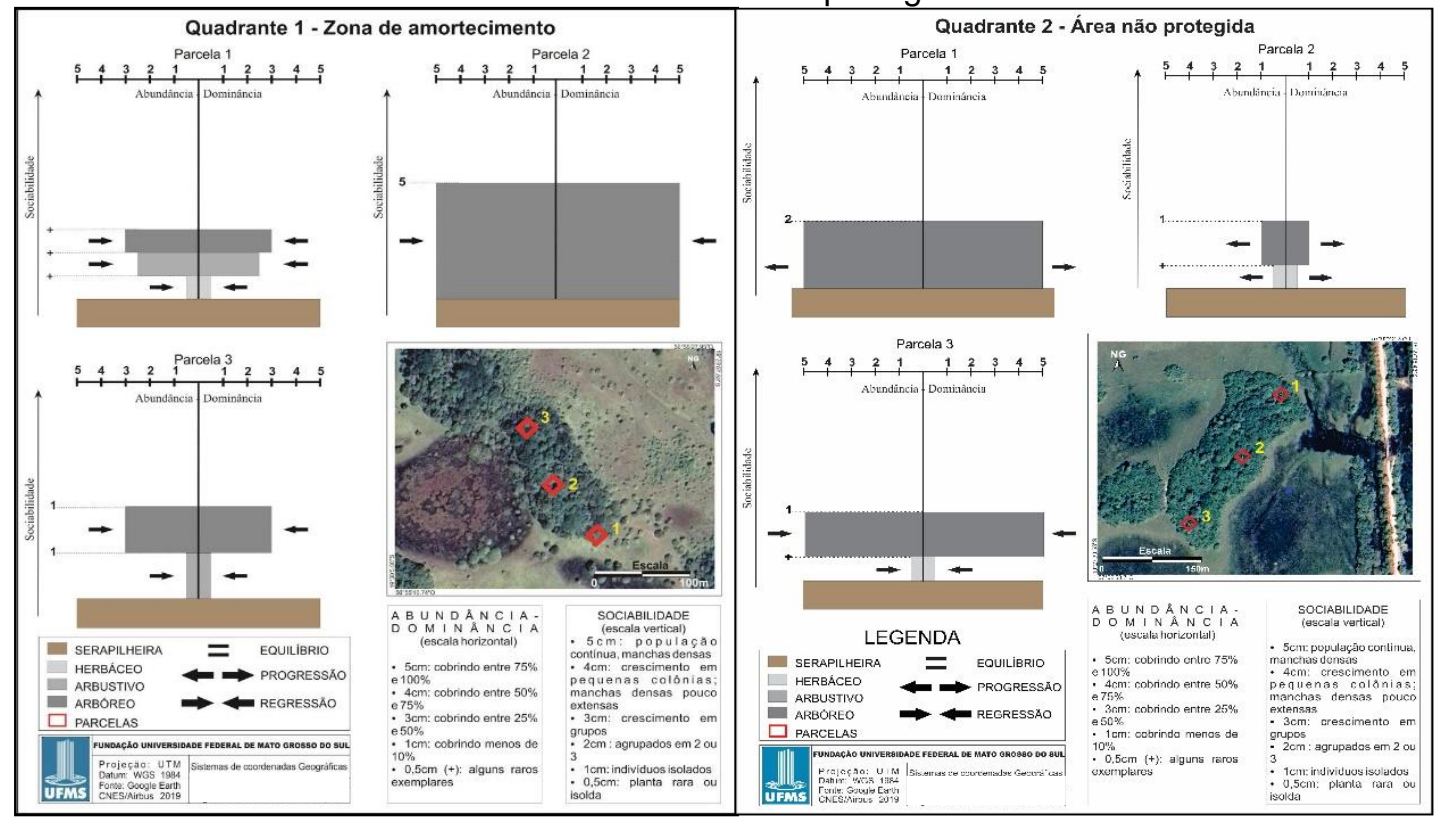

Fonte: BONI, 2020.

Na cordilheira localizada na área não protegida (Figura 4), na Parcela 1 encontrou-se espécies do estrato arbóreo (cobrindo 75 a 100\%) e dominância representada pelos Acuris que cobriam a maior parte do dossel. A sociabilidade do estrato, de modo geral, deu-se em grupos sugerindo a progressão do estrato.

Referente a Parcela 2, no estrato arbóreo, foram encontradas plântulas4 de variadas espécies; entretanto, poucas espécies foram identificadas em estágio bem desenvolvido (adulto), tendo baixa abundância-dominância e baixa sociabilidade. O estrato arbóreo, portanto, ocupou menor área do dossel, caracterizando uma abundância-dominância de 1, plantas abundantes; porém que não cobrem área superior a $10 \%$. A pouca cobertura do dossel oferece vantagem para as sementes germinarem, beneficiando a ocupação de espécies de outros estratos vegetacionais, no entanto permite inicialmente a presença de espécies mais resistentes, o que pode explicar a identificação no estrato herbáceo de apenas uma espécie (KERBAUY, 2008; TAIZ et al., 2017).

$\mathrm{Na}$ Parcela 3, o estrato arbóreo foi representado exclusivamente pelos acuris, que compuseram a abundância-dominância superiora $75 \%$, com progressão do estrato, também havendo várias plântulas da espécie. A sociabilidade do estrato deu-se em indivíduos isolados. Por fim, no estrato herbáceo, foi encontrado apenas uma espécie representada por um indivíduo, dessa forma, em regressão.

Como visto, o acuri está presente na maior parte das parcelas. Essa planta possui frutos consumidos pelo gado que, por sua vez, proporciona a disseminação da espécie considerada monodominante, com características como resistência e adaptação. $O$ acuri justifica-se por ser uma espécie que se adapta ao sol e aos períodos de inundação; por isso está localizado na borda e não no centro das cordilheiras, até porque no centro destas unidades, a existência da vegetação arbórea mais presente

4 A plântula é uma planta jovem, resultante do desenvolvimento inicial do embrião.

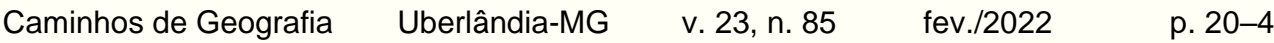

Página 28 
não permite a incidência do sol com a mesma intensidade (FERREIRA et al., 2001; NEGRELLI, 2003).

Com base nas observações das características e configuração da cobertura vegetal, tanto de sua estrutura quanto composição, as quais se diferenciam entre as unidades estudadas e até mesmo dentro destas unidades, verifica-se que as condições microclimáticas podem ser afetadas pela morfologia dessas paisagens.

A partir das análises microclimáticas, percebe-se que a área central das cordilheiras, ou seja, área com cobertura vegetal predominante, apresentou, naquela localizada em Zona de Amortecimento, temperatura máxima de $32,5^{\circ} \mathrm{C}$, às $13 \mathrm{~h}$ e mimina de $23,7^{\circ} \mathrm{C}$, às $05 \mathrm{~h}$, no dia $19 / 09 / 2018$. E na cordilheira da área não protegida, $37,1^{\circ} \mathrm{C}$, às $13 \mathrm{~h}$ e $24,8^{\circ} \mathrm{C}$, às $04 \mathrm{~h}$, do dia $30 / 11 / 2019$. Com base nesses dados, a amplitude térmica foi de $8,8^{\circ} \mathrm{C}$ e de $12,3^{\circ} \mathrm{C}$, respectivamente.

Com base nos dados referentes à umidade, nas áreas centrais das cordilheiras (Figura 5) nota-se uma similaridade em relação a temperatura, com poucas diferenciações. No Quadrante 2 (área não protegida), o maior índice de umidade foi de $90 \%$ e no Quadrante 1 (Zona de Amortecimento) foi de $87 \%$, ambos às $04 \mathrm{~h}$. E a menor umidade foi de $45,5 \%$ e $57,5 \%$, respectivamente. É perceptível que o maior e menor índice de umidade foram identificados na área não protegida, em comparação a Zona de Amortecimento, revelando maior amplitude.

Figura 5 - Temperatura e umidade da área central das cordilheiras.

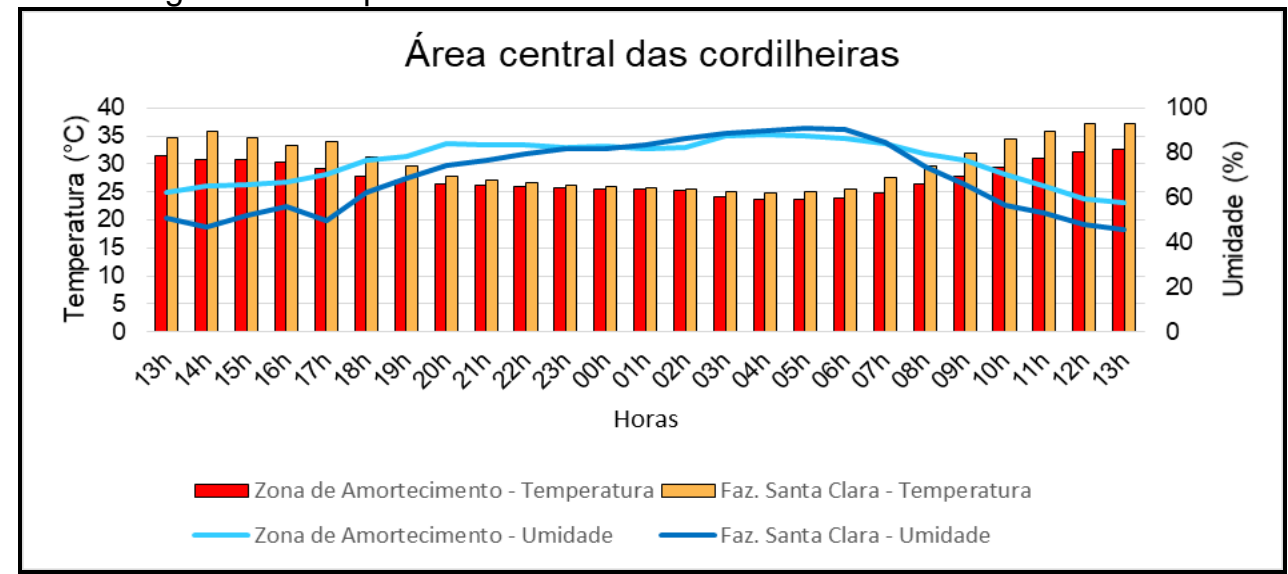

Fonte: BONI, 2020.

Em comparação entre as áreas de campo aberto, externas às Cordilheiras amostrais, a temperatura máxima e mínima da Zona de Amortecimento, foi respectivamente $36,2^{\circ} \mathrm{C}$, às $13 \mathrm{~h}$ e $21,8^{\circ} \mathrm{C}$, às $04 \mathrm{~h}$ do dia $30 / 11 / 2019$. Na área não protegida, a maior temperatura foi de $40,2^{\circ} \mathrm{C}$, às $10 \mathrm{~h}$ e a menor $24^{\circ} \mathrm{C}$, às $04 \mathrm{~h}$ do dia 19/09/2018. No entanto, durante o dia 18/09/2018, às 14 h e no dia $19 / 09 / 2018$, às $13 \mathrm{~h}$, foi atingida a temperatura de $40^{\circ} \mathrm{C}$ no local referente a área não protegida. A amplitude térmica da Zona de Amortecimento foi de $14,4^{\circ}$ e na área não protegida de $16,2^{\circ}$ (Figura 6 ).

Figura 6 - Temperatura e umidade da área externa das cordilheiras.

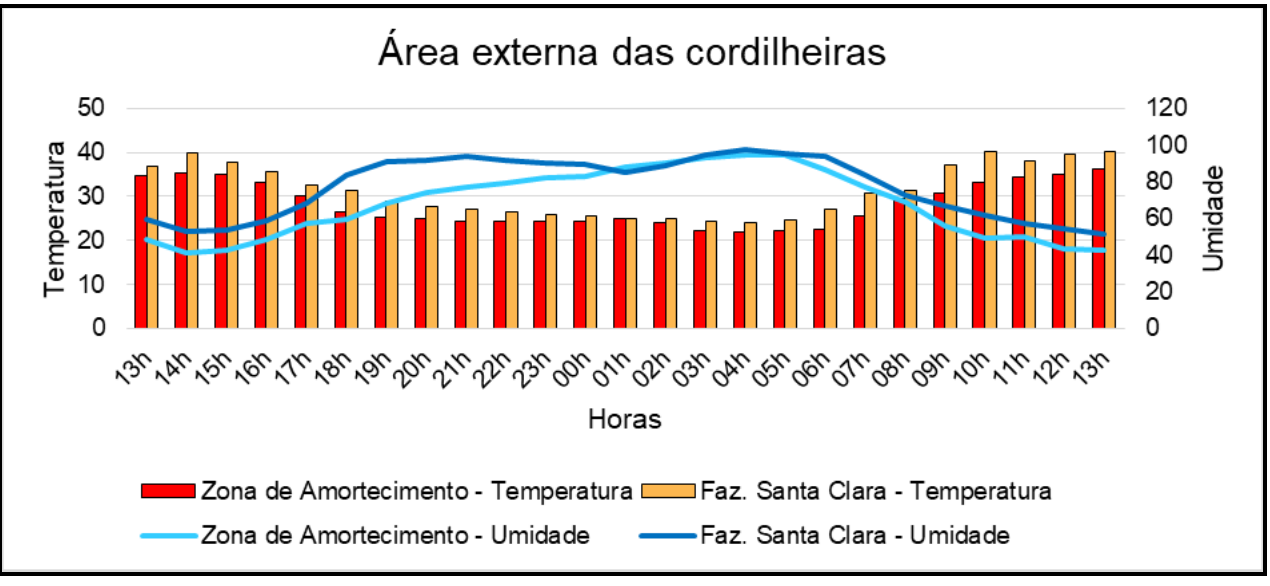


Fonte: BONI, 2020.

Segundo, Mendonça e Dani-Oliveira (2007), as alterações diurnas de temperatura ocorrem devido ao aquecimento do ar ser mais rápido, tendo início ao nascer do sol e desdobra-se com a perda de energia da superfície através do processo de emissão e condução de calor.

Nota-se ainda que nas áreas com vegetação arbórea, centro das cordilheiras, possuem oscilação de temperatura e umidade menos acentuada, em relação as regiões de campo aberto. Complementando, Silva, Gradella e Decco (2017), com estudos comparativos em unidades de paisagem do Pantanal, notaram que o aquecimento da superfície, a partir do nascer do sol e com o resfriamento no pôr do sol, é tido de forma gradual em áreas com vegetação arbórea.

Com base nos dados climáticos, o centro das cordilheiras possui temperaturas menores em relação ao campo ao seu redor. Na comparação entre as partes internas das cordilheiras amostrais verificouse um comportamento térmico diferente, devido à formação vegetal de cada uma. Percebe-se, ainda, que a cordilheira da Zona de Amortecimento, que possui grande parte de vegetação arbórea, responsáveis por conservar a temperatura e a umidade no interior dela. Assim que a perda de calor é menor, consequentemente, a amplitude térmica também seja menor, segundo Silva, Gradella e Decco (2017) a perda de temperatura e umidade em campos abertos é considerada rápida e abrupta, quando comparado com as áreas centrais da cordilheira e ainda corroborando afirmam que a refletância de energia é maior e consequentemente o calor local devido à falta de vegetação arbórea.

Além das relações microclimáticas influenciadas pela vegetação e vise e versa, os atributos topográficos influenciam nas características dos tipos de solos e, no caso do Pantanal, a periodicidade das inundações também contribuem para a singularidade dessas unidades. Essas especificações refletem diretamente na disposição da vegetação e na estrutura das unidades de paisagem (CAMPOS, 2012; SOARES, SILVA e FERRARI, 2006).

Na perspectiva topográfica, o perfil tridimensional da cordilheira localizada na área de amortecimento de UC (Quadrante 1), revelou que o centro e as extremidades horizontais da cordilheira são mais elevados; já nas bordas laterais, é notória uma diminuição considerável na altura em relação ao centro. Isso revela uma semelhança com as características já estabelecidas nas bibliografias citadas (RADAMBRASIL, 1982 e SOARES, SOARES e ASSINE, 2003).

Durante o trabalho de campo, constatou-se que a cordilheira possuia uma diferença significativa de altimetria em relação borda-centro-borda (Figura 7), o que discorda das descrições de Souza, Lani e Sousa (2006), de que as cordilheiras possuem formato com pequena declividade na interface com o campo de inundação, na qual a posição central é elevada e simétrica e não sofre inundações. Ao contrário, a Cordilheira analisada possui diversas ondulações suaves e irregulares; com áreas mais deprimidas na direção norte e alguns "picos", pontualmente localizados. Isso demonstra que as cordilheiras não são exclusivamente formações regulares e completamente simétricas.

Figura 7 - Representação das cordilheiras da área 1, Zona de Amortecimento em 3D.

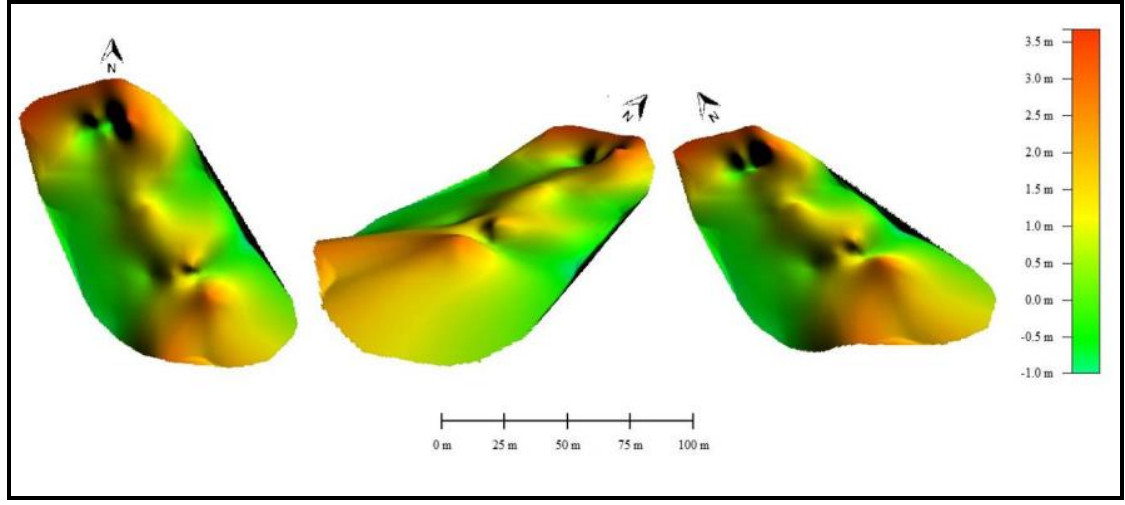

Fonte: BONI, 2020.

No quadrante 2 (Figura 8), área não protegida, é possível notar a evidência no centro da cordilheira, chegando a pontos negativos de altura, ou seja, mais baixo que a superfície ao redor dela. Tais características demonstram que as áreas com maior altura no interior da cordilheira são as bordas verticais centrais, nos quais chegam a $2,5 \mathrm{~m}$. Analisando as particularidades, foi verificado que a presença de água no período de inundação apresenta-se contínua, ocasionando uma erosão

$\begin{array}{llllll}\text { Caminhos de Geografia } & \text { Uberlândia-MG } & \text { v. 23, n. } 85 & \text { fev./2022 } & \text { p. 20-41 } & \text { Página } 30\end{array}$


considerável. É notório essa observação, quando em campo foi analisado a possível direção da água pelas partes mais abtidas da cordilheira.

Figura 8 - Representação das cordilheiras da área 2, área não protegida em 3D.

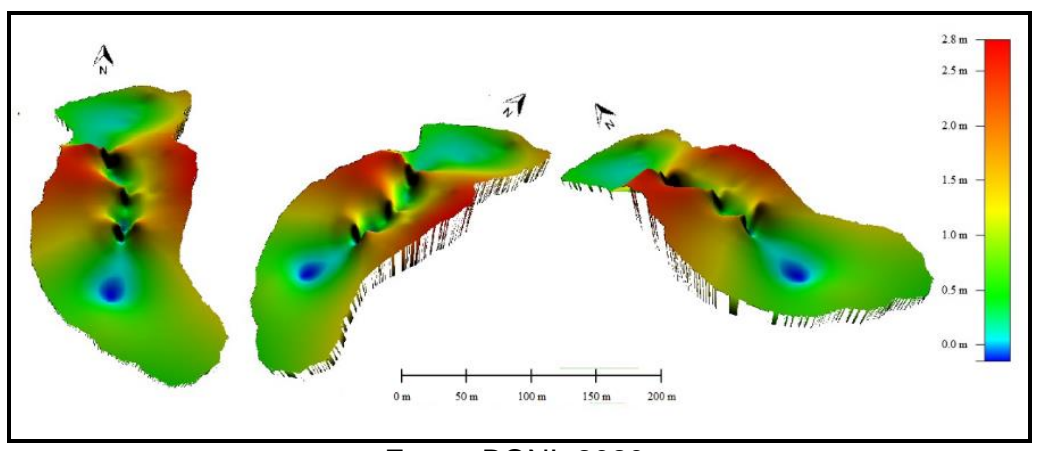

Fonte: BONI, 2020.

A configuração topográfica descrita revela que água, provindas das inundações me períodos de cheia, pode ser um elemento fundamental na organização pedomorfológica que por sua vez influencia a organização da cobertura vegetal, além disso essa configuração topográfica, dependendo das características físicas da cobertura pedológica pode dinamizar percolação de sedimentos ocasionando sistema erosivos locais. Por isso, Cardoso et al. (2016) afirmaram que para uma compreensão mais abrangente do solo na paisagem do Pantanal, o grande desafio é entender a interação de ambos.

Nesse sentido, o ponto T1 na cordilheira localizada na Zona de Amortecimento de UC (Figura 7), localizado na borda da unidade, possui um relevo plano, considerado bem drenado, com presença da pecuária e vegetação composta por gramíneas e por vegetação de médio porte, com presença de canjiqueiras (Byrsonima orbignyana A. Juss.) distribuídas de forma esparsa.

No perfil pedológico (Figura 9) a cor predominante das amostras é cinza claro (10YR 7/2) com variações, através da análise do perfil percebe-se a migração de partículas de solos para profundidades maiores, o que envolve processos pedogenéticos interligados à oscilação do lençol freático que influenciam no processo de lixiviação, responsável pela transferência de partículas. A rede de drenagem é um dos principais motivos de percolação dos nutrientes do solo no Pantanal, que influencia na permanência da água durante quase seis meses do ano sobre a superfície, segundo Cardoso et al. (2016). A granulometria, pode ser a característica facilitadora desta dinâmica de drenagem, uma vez que é predominantemente arenosa, identificando areia fina em maior quantidade de $39 \%$ a $46 \%$, seguida de areia muito fina (24\% a $33 \%$ ) e areia média (17\% a $29 \%)$. 
Figura 9 - Representação dos perfis pedológicos e histogramas relacionado a cordilheira a Zona de Amortecimento.

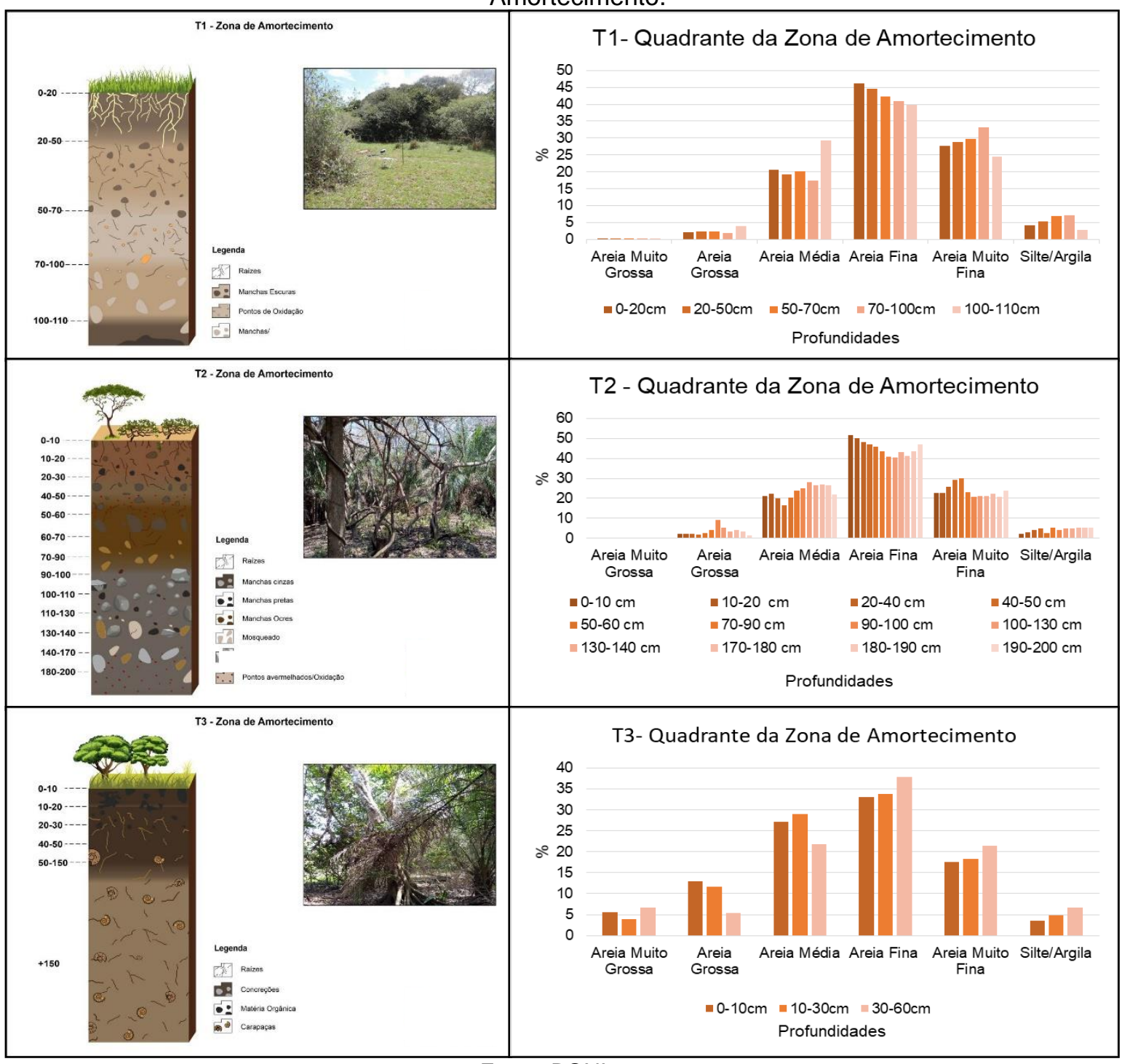

Fonte: BONI, 2020.

O ponto T2 localizado na borda da cordilheira foi caracterizado com presença excessiva de vegetação denominada popularmente como canjiqueiras e gramíneas na superfície. As cores do solo variam entre marrom (7.5YR 4/4), marrom claro (10YR 6/3) e cinza escuro (10YR 4/1), nota-se no corpo do perfil a presença de nódulos e agregados, manchas escuras e ocres demonstrando o processo de percolação pela presença do lençol freático. A análise granulométrica que prevalece sedimentos caracterizados como areia fina ( $40 \%$ a $51 \%)$, seguido de areia muito fina $(20 \%$ a $30 \%)$ e areia média (16\% a $27 \%)$.

O ponto T3 está localizado no centro da cordilheira a cobertura vegetal constituída de vegetação arbórea densa, com presença de palmeiras de acuris (Attalea phalerata Mart.), classificadas como jovens, com presença considerável de serrapilheira na superfície. A presença de acuri no centro da cordilheira é marcante, segundo Carvalho Filho et al. (2000), a presença dessa vegetação traz um significado importante em relação ao solo, ou seja, em superfícies com presença desse tipo de 
vegetação, identifica-se uma melhor condição química do solo em relação aos valores de soma de bases e teores.

As cores encontradas no perfil variam entre marrom muito escuro (10YR 2/2), marrom (10YR 5/3) e cor cinza claro (10YR 7/2). Durante as tradagens identificou-se nódulos, presença de carapaças e moluscos juntamente com afloramento rochoso, característica essa, justificada pela moderada profundidade de tradagem. A análise granulométrica possibilitou identificar que areia fina possui a maior quantidade de sedimentos (33\% a $37 \%)$, seguido de área média $(21 \%$ a $28 \%)$ e areia muito fina (17\% a $21 \%)$.

$\mathrm{Na}$ área identificada como não protegida, as coletas de solo e a análise granulométrica, foram realizadas através de tradagem ao centro (T4) e duas trincheiras nas bordas (T5 e T6).

A tradagem realizada ao centro da cordilheira, T4, possuia características diferenciadas como a presença de plântulas de acuris ao centro, como já visto na pirâmide de vegetação, além de presença de vegetação arbórea caídas e poucas árvores de grande porte. Nesse ponto amostral, sobre a superfície, o material pedológico encontra-se com matéria orgânica em decomposição, implicando na coloração do solo, marrom muito escuro (7.5YR $2.5 / 2)$, até $40 \mathrm{~cm}$ de profundidade. Nas demais profundidades, a cor marrom (7.5YR 4/2) foi predominante, encontrando carapaças e concreções acinzentadas.

Sobre a análise granulométrica (Figura 10), a maior parte dos sedimentos são considerados areia fina em todas as profundidades (de $32 \%$ a $33 \%$ ). Seguidamente, de areia muito fina (de 23 a $26 \%$ ), semelhante à areia média (de 22 a $25 \%$ ).

Figura 10 - Representação dos perfis pedológicos e histogramas relacionado a cordilheira a área não protegida. 


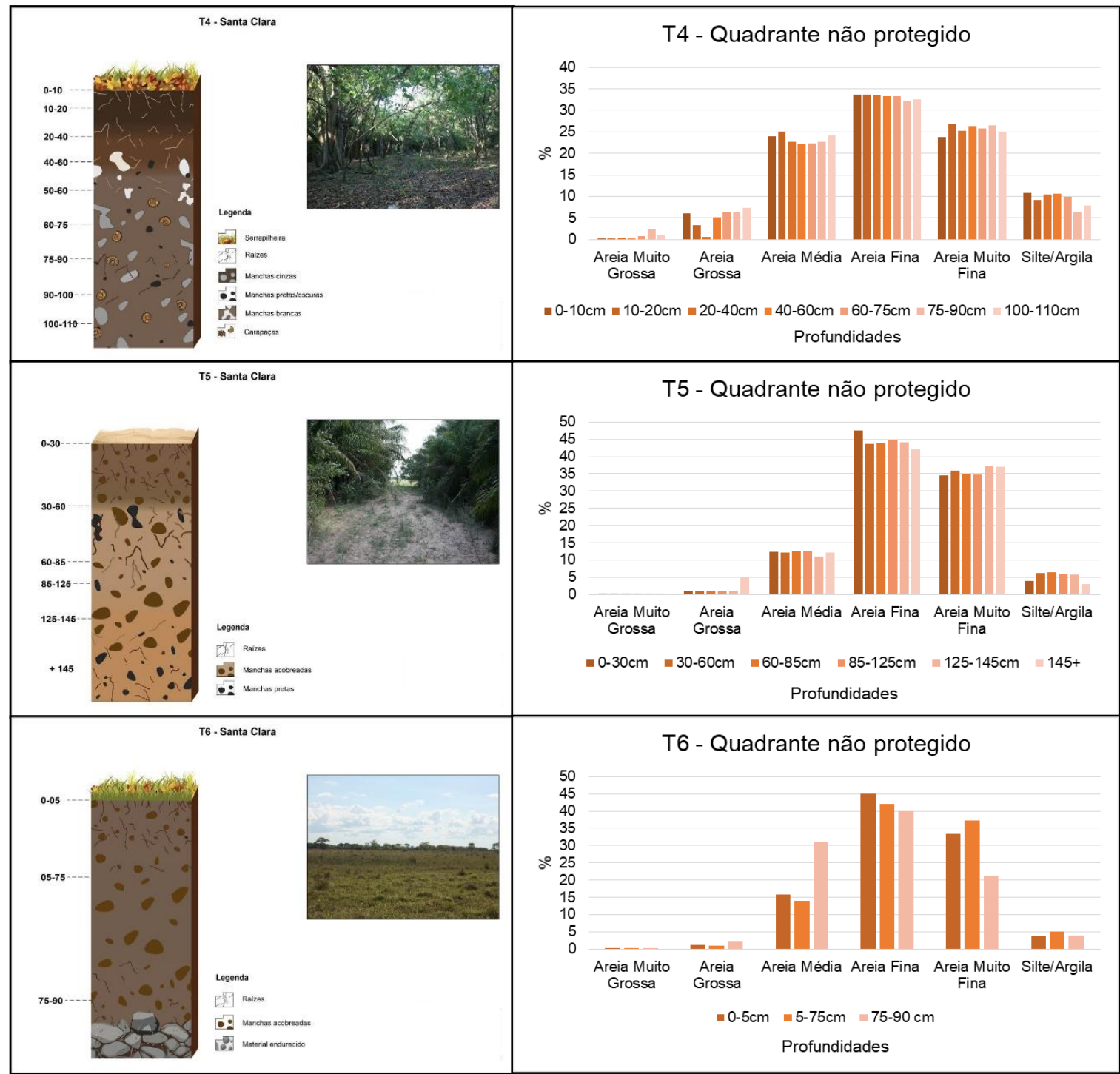

Fonte: BONI, 2020.

Ao comparar as análises do topo de ambas cordilheiras, da zona de amortecimento do PEPRN (T3) e a área não protegida (T4) nota-se divergências como na menor quantidade de areia muito grossa $e$ areia grossa, além de maior quantidade de areia muito fina, silte/argila em T4. No entanto, areia média e areia fina possuem quantidades semelhantes quanto a profundidades.

Já em relação ao ponto T5, a cor predominante 7.5YR 6/4 (Marrom Claro), com textura fina e manchas ocres resultado da percolação da água. Em relação análise granulometrica percebe-se que a areia fina representa quase metade da amostra ( 41 a $47 \%$ ), seguida de areia muito fina (23 a $37 \%$ ).

No último ponto de análise, T6, localizado em outra borda, próxima da Estrada Parque, com presença de gramíneas densas e vegetação de pequeno porte esparsada, com terreno levemente acidentado. A cor predominante foi a cor marrom ( 7.5YR 4/2), nota-se uma mudança em relação a estrutura que nas amostras anteriores foram consideradas soltas e aqui sub-angular. Ainda, próximo a $1 \mathrm{~m}$ de profundidade, notou-se a presença de um material muito endurecido, conhecido como laje5, não permitindo atingir maiores profundidades. Em relação a análise granulométrica percebe-se que a areia fina possui maior quantidade de sedimentos (39 a 45\%), seguido de areia muito fina (21 a $37 \%$ ).

5 A laje é considerada uma formação geológica caracterizada pelo acúmulo de sais enrijecidos, não constituem nenhuma classe de solos exclusivas e são comuns em planossolos, chernossolos (SILVA, 2012; QUEIROZ 2018). 
Em relação aos solos, foi realizado análise química de algumas amostras, de acordo com suas características físicas, percebeu que o pH (potencial hidrogênico) apresentam variações entre ácido e alcalino, segundo as classes de interpretação para acidez ativa do solo $(\mathrm{pH})$ proposta por Cardoso, Fernandes e Fernandes (2009). As áreas de borda de ambas as cordilheiras (amostras de T1 (0-20 e 20-50), T2 (0-20 e 60-70), T6 (05-75 e 75-90)) possuem acidez muito elevada; já em profundidade na borda da área de amortecimento, em T1 (70-100), é considerada apenas elevada; por fim, em superfície na borda da cordilheira em área protegida, T6 (0-5), possui acidez média; contudo, ambas amostras estão localizadas nas bordas das cordilheiras analisadas. Foram classificadas como acidez fraca, as bordas da cordilheira da área de amortecimento, exceto em superfície em T2 (110-130 e 180-200) e em todas as profundidades de T3 e T5. Contrário às amostras anteriores, as profundidades de T4 são todas consideradas alcalinas fracas. Em nenhuma amostra analisada encontrou-se pH neutro, conforme a Tabela 4.

Tabela 4 - Resultados analíticos de elementos.

\begin{tabular}{|c|c|c|c|c|c|c|c|}
\hline Amostra & $\overline{P H}$ & $\begin{array}{c}\text { MO } \\
\text { (Matéria } \\
\text { orgânica) }\end{array}$ & $\begin{array}{c}\text { Fosfóro } \\
\text { (P) }\end{array}$ & $\begin{array}{l}\text { Cálcio } \\
\text { (Ca) }\end{array}$ & $\begin{array}{l}\text { Magnésio } \\
(\mathrm{Mg})\end{array}$ & $\begin{array}{c}\mathrm{H}+\mathrm{Al} \\
\text { (Hidrogênio } \\
+ \text { Alumínio) }\end{array}$ & $\begin{array}{c}\text { CTC } \\
\text { (Capacida-de } \\
\text { de troca de } \\
\text { cátions) }\end{array}$ \\
\hline T1 0-20 & $4,2^{* * * * *}$ & 21 & $8^{*}$ & 3 & 1 & 20 & 24,9 \\
\hline T1 20-50 & 4,3 & 17 & 7 & 3 & 1 & 12 & 16,7 \\
\hline T1 70-100 & 4,9 & 16 & 7 & $4^{* *}$ & 1 & 8 & 13,6 \\
\hline T2 0-20 & 4,1 & 22 & 9 & 3 & 1 & 18 & 23.1 \\
\hline T2 60-70 & 3,8 & 18 & 7 & 6 & 6 & 20 & 33,8 \\
\hline $\begin{array}{c}\text { T2 110- } \\
130\end{array}$ & 6,8 & 18 & 7 & 38 & 164 & 11 & 215,1 \\
\hline $\begin{array}{c}\text { T2 180- } \\
200\end{array}$ & 6,2 & 18 & 9 & 47 & 182 & 9 & 241,1 \\
\hline T3 0-10 & 6,8 & 39 & $1010^{\star \star \star}$ & 3722 & 350 & 8 & 4083,2 \\
\hline T3 30-60 & 6,9 & 30 & 120 & 1940 & 362 & 8 & 2315,6 \\
\hline T4 0-10 & $7,1^{* \star * *}$ & 51 & 140 & 1734 & 280 & 8 & 2025,2 \\
\hline T4 40-60 & 7,3 & 36 & 44 & 1586 & 326 & 8 & 1925,5 \\
\hline $\begin{array}{c}\text { T4 100- } \\
110 \\
\end{array}$ & 7,7 & 32 & 96 & 3524 & 436 & 6 & 3974,6 \\
\hline T5 0-30 & 6,9 & 18 & 12 & 16 & 3 & 11 & 30,9 \\
\hline T5 30-60 & 6,4 & 15 & 9 & 6 & 2 & 10 & 18,7 \\
\hline T5 85-125 & 6,3 & 15 & 8 & 3 & 1 & 9 & 13,6 \\
\hline T6 0-5 & 5,3 & 23 & 8 & 9 & 4 & 16 & 31,1 \\
\hline T6 5-75 & 4,2 & 16 & 7 & 3 & 2 & 13 & 19,0 \\
\hline T6 75-90 & 3,8 & 15 & 6 & 10 & 8 & 64 & 83,5 \\
\hline
\end{tabular}

Fonte: BONI, 2020.

*a cor vermelha designa teor baixo.

**a cor azul designa teor médio.

***a cor verde designa o teor alto.

**** a cor marrom designa o $\mathrm{pH}$ ácido.

***** a cor lilás designa o $\mathrm{pH}$ alcalino.

As análises deixam perceptível que a presença de Fósforo $(\mathrm{P})$ implica no desenvolvimento do caule, afetando a coloração das folhas. Sabendo disso, os pontos T1, T2 da cordilheira da Zona de Amortecimento e T5 e T6 da não protegida, possuem baixos teores de fósforo. Isso explica o não desenvolvimento de árvores com caules desenvolvidos, tendo como principal vegetação gramíneas ou canjiqueiras. Nota-se, por fim, que a quantidade de matéria orgânica é média em ambas profundidades. Em contrapartida, T3 (centro da cordilheira da Zona de Amortecimento), possui o teor de fósforo é considerado alto, além de grande teor de matéria orgânica, considerada, conforme 
parâmetros, como alta. Segundo Rossi (2013), a produção de fósforo tem como origem, resíduos vegetais adicionados ao solo, do tecido microbiano e dos produtos de sua decomposição.

Outro elemento afetado pelo $\mathrm{pH}$ ácido é o cálcio $(\mathrm{Ca})$, responsável pelo fortalecimento das raízes e folhas, além de realizar o equilíbrio entre alcalinidade e acidez da seiva das plantas. Ainda, possibilita que os microrganismos decomponham a matéria orgânica com fim à liberação de nutrientes e aumentam a estrutura e capacidade de retenção de água dos solos (NUNES, 2016).

Comparando as análises das duas cordilheiras, notou-se que os pontos centrais T3 e T4 possuem teores considerados altos de cálcio, justificadas em amostras T2 (110-130 e 180-200), T5 (0-30), T6 (0-5 e 75-90). Todas as amostras listadas, em campo, possuíam poucas raízes, manchas e concreções esbranquiçadas revelando a presença do cálcio. Diferentemente das amostras T1, T2 (020), T5 (85-125) e T6 (5-75), nos quais o parâmetro de cálcio apresentou-se como baixo, as propriedades visualizadas em campo, como manchas escuras ou acobreadas, sem presença de raízes. Justificando assim que a carência de cálcio provoca má formação nas folhas jovens, levando sua forma a morrer da extremidade para o centro, além de redução do crescimento e presença de raízes com cor castanho (NUNES, 2016).

Ainda foi constatada a presença do magnésio, outro macronutriente importante para o desenvolvimento da vegetação, devido ser parte integrante da molécula da clorofila (NUNES, 2016). O maior teor de magnésio foi encontrado em T2 (110-130 e 180-200), T3 e T4. Verifica-se que os níveis desse elemento em T2 não é compatível com a quantidade de fósforo, pois o excesso provoca interferência na absorção do cálcio.

Levando em consideração que todos os pontos de coleta, exceto T4, demonstraram que o solo é considerado ácido, Moraes Neto (2009) aponta que o pH do solo está relacionado com a presença de sais e elevada saturação de base. O autor aponta, ainda, que os principais responsáveis pela acidez do solo é hidrogênio e alumínio. É necessário levar em consideração que a água quando entra em contato com os cátions de alumínio torna o pH cada vez mais ácido; assim justifica-se a acidez das profundidades T1, T2, T3, T5 e T6, por força da dinâmica natural do Pantanal com o longo período de cheia.

O CTC (capacidade de troca de cátions) é o número total de cátions trocáveis que um solo pode reter; a capacidade de troca depende da quantidade e do tipo de argila e de matéria orgânica presente (MEDEIROS et al., 2008). No caso do Pantanal com solos pouco intemperizados e uma quantidade relativamente alta de matéria orgânica, notam-se valores altos de CTC.

Nota-se que os pontos com alto teor de trocas de cátions estão localizados na parte mais alta da cordilheira, o centro; principalmente em T3, incluindo a profundidade de 30-60, com MO (matéria orgânica média) e T4; todas as profundidades, o CTC e MO possuem teores maiores em T4, gradativamente, em relação às profundidades, conforme o processo de translocação, ou seja, o material está percolando de acordo com a profundidade.

Estes pontos citados têm em comum uma grande quantidade de serrapilheira em decomposição, devido à presença da cobertura vegetal nessas unidades. No entanto, mesmo os dois pontos serem caracterizados como centro das cordilheiras nota-se uma quantidade menor de serrapilheira em T3 devido abertura de clareira neste ponto, por isso uma quantidade menor de CTC.

Como visto, todas as análises granulométricas demonstram uma maior quantidade de areia fina, areia muito fina e areia média. O silte/argila analisados são variáveis em cada amostra, mas, a partir das análises, nota-se que a interação da maior quantidade de matéria orgânica em T3 e T4, centro das cordilheiras, junto com a argila provoca um teor elevado de trocas de cátions (CTC), o qual provoca estabilidade do solo e a disponibilidade de nutrientes, demonstrando assim a importância da matéria orgânica para o solo. Já o pH de ambos os pontos é mais próximo do neutro, influenciando no desenvolvimento da vegetação, a qual, por sua vez, alimenta o referido solo ao proporcionar a formação de serrapilheira.

No entanto, acerca dos elementos químicos analisados, percebe-se que T3, tradagem localizada ao centro da cordilheira, na Zona de Amortecimento, possui uma dinâmica diferenciada, comparativamente, aos demais pontos de análises. Também percebe-se que os pontos mais altos, ou seja, centrais das cordilheiras são possuidores de todos os elementos químicos propícios ao desenvolvimento completo da vegetação e do solo; diferentemente dos demais pontos de análise (T1,

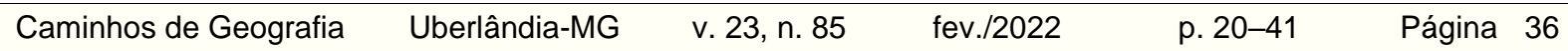


T2, T5 e T6) que possuem déficit químico de potássio, de fósforo e de magnésio além do pH variando entre acidez muito elevada e acidez fraca, provocado também pela influência do regime hídrico.

Dessa forma, em relação ao ponto T1 e T2 percebe-se uma espacialização de vegetação arbórea em maior quantidade, em ambos os pontos a topografia é considerada mais baixa e o contato com água por maior tempo influenciam na falta de nutrientes como fósforo, cálcio e magnésio. $\mathrm{O}$ pH do solo também está associado à presença de $\mathrm{H}+\mathrm{Al}$, nesse sentido, notam-se os maiores teores desses elementos juntos nas bordas das cordilheiras, podendo ser associados à presença de formação monodominante, como as canjiqueiras.

Com isso, o problema referente à fertilidade do solo foi sempre constatado em áreas de campo, onde a pecuária é mais intensa. No entanto, não se pode afirmar que a área com proteção ambiental possui melhores condições biogeográficas: existe uma semelhança entre as áreas de campo e as áreas centrais das cordilheiras. Em ambos os ambientes, notou-se que a topografia da Zona de Amortecimento tem maiores características preservadas quanto ao formato e organização da vegetação; diferentemente da cordilheira em área não protegida, que tem o processo de erosão mais aparente e, consequentemente, altera mais rapidamente os atributos naturais na cordilheira.

As observações do solo e da vegetação referentes a T4, demonstraram a presença de grandes clareiras, nas quais a parcela 2 evidencia a falta de vegetação arbórea em progressão. No entanto, essa área possui a maior quantidade de matéria orgânica dos três pontos de análise da área não protegida, com presenças de carapaças que indicam um $\mathrm{pH}$ alcalino. Mas, com a presença de clareiras que permitem a entrada e saída de calor com maior facilidade, justificando assim uma maior amplitude térmica.

Em T5 e T6, a cobertura do dossel é tomada por poucos acuris, bem desenvolvidos, além de uma grande quantidade de plântulas, ambos pertencentes ao estrato arbóreo (75 a 100\%). Do ponto de vista biológico, no caso de T5 com parcela 3, sugere-se uma competição entre as plântulas com espécies de outros estratos, por efeito da maior incidência solar. A semelhança entre as duas áreas de coletas, parcela 1 e 3 , se dá pela dominância dessa espécie em sincronia com o processo de inundação. Essa área é considerada "baixa", topograficamente, fato que facilita o seu desenvolvimento. Há de se levar em conta também o baixo índice de fósforo, possivelmente ocasionado pela presença constante da água na superfície, no período de inundação.

Assim, percebe-se nessas áreas uma constante competição entre as espécies vegetais, principalmente aquelas em que seus indivíduos se adaptam mais facilmente às mudanças locais e, por isso, estão conseguindo efetuar o processo de expansão de suas áreas de ocupação. Neste caso, os processos erosivos e, consequentemente, a mudança de dinâmica de inundação das cordilheiras são responsáveis pelo predomínio da presença de acuris, inclusive em áreas centrais da cordilheira.

\section{CONSIDERAÇÕES FINAIS}

A análise biogeográfica dos elementos da paisagem demonstra muitas semelhanças entre as cordilheiras, objetos de comparação; principalmente, levando em conta os pontos de análise, ou seja, o centro e a área de campo aberto.

Os resultados deixam clara, uma necessidade de preservação das cordilheiras, por possuírem solos ricos em elementos químicos, logo, mais férteis que as áreas de campo aberto e com padrões térmicos com menores amplitudes e, portanto, configuram unidades de paisagem essenciais para o equilíbrio biogeográfico.

A presença do gado nos ambientes de observação é frequente. Após análise pedológica e topográfica, identificou-se que a cordilheira da área não protegida possui traços de degradação ambiental mais evidentes, como a presença da erosão, o pisoteio do gado, associados às deformações da cordilheira. No entanto, na cordilheira da Zona de Amortecimento, o traço desta atividade também foi evidente, podendo ser uma indicação para modificações através da pecuária nas áreas direcionadas à preservação futuramente. Assim como, a vegetação na qual muitas vezes um estrato de vegetação encontra-se dominante e em progressão impedindo o desenvolvimento de demais estratos, deixando claro um desequilíbrio ambiental.

$\begin{array}{llllll}\text { Caminhos de Geografia } & \text { Uberlândia-MG } & \text { v. 23, n. } 85 & \text { fev./2022 } & \text { p. 20-41 } & \text { Página } 37\end{array}$


Sabe-se que a pecuária é a principal atividade econômica do Pantanal, e os aspectos históricos e culturais devem ser preservados, no entanto, a busca pelo maior poderio econômico, deixa esquecidos os aspectos naturais essenciais para o desenvolvimento de tal atividade. Por isso, é necessário a busca pela sustentabilidade e preservação dessa paisagem única.

Diante disso, torna-se indiscutível a contribuição das cordilheiras e das formações campestres para a dinâmica natural do Pantanal. Por outro lado, a inserção de vegetação não pertencente a este ambiente tem-Ihe provocado prejuízos e danos, alterando a organização das unidades de paisagem, bem como do microclima local, a microbiologia do solo e os estratos de vegetação.

\section{REFERENCIAS BIBLIOGRÁFICAS}

ADÁMOLI, J. O pantanal e suas relações fitogeográficas com os cerrados. Discussão sobre o conceito de "complexo do pantanal. In: CONGRESSO NACIONAL DE BOTÂNICA, 32., 1982, Teresina. Anais... Teresina: Sociedade Botânica do Brasil, 1982. p.109-119.

ALBUQUERQUE, E. S.; CANDIOTTO, L. Z. P.; CARRIJO, B. R.; MONASTIRSKY, L. B. A nova natureza do mundo e a necessidade de uma biogeografia "social". Revista Geosul. v. 19, n. 38. p. 141-158 Florianópolis, 2004.

ALMEIDA, B. G.; DONAGEMMA, G. K. RUIZ, H. A.; BRAIDA, J. A.; VIANA, J. H. M.; REICHERT, J. M. M.; OLIVEIRA, L. B.; CEDDIA, M. B.; WADT, P. S.; FERNANDES, R. B. A.; DECHEN, S. C. F.; KLEIN, V. A.; TEIXEIRA, W. G. Padronização de Métodos para Análise Granulométrica no Brasil. Comunicado Técnico 66. Embrapa: Rio de Janeiro. 2012.

ALVARENGA, S. M.; BRASIL, A. E.; PINHEIRO, R.; KUX, H. J. H. (1984) Estudo geomorfológico aplicado à Bacia do Alto Paraguai e Pantanais Mato-grossenses. Boletim Técnico. Salvador: Projeto Radambrasil, Série Geomorfológica 1. p. 89-183.

ANDRADE, B. S. Análise da paisagem de ambientes florestais não inundáveis no Pantanal do Abobral, Mato Grosso do Sul. 2017. 91 f. Dissertação (Mestrado em Meio Ambiente e Desenvolvimento Regional) - Universidade Anhanguera-Uniderp, Campo Grande. 2017.

ASSINE, M. L.; SOARES, P. C. Quaternary of the Pantanal, West-Central Brazil. Quaternary International, vol. 114, n. 1, p. 23-34, 2004.

ASSINE, M. Sedimentação na Bacia do Pantanal Matogrossense, centro-oeste Brasil. 2003. 106 f. Tese (Livre Docência) - Instituto de Geociências e Ciências Exatas, Universidade Estadual Paulista, Rio Claro. 2003.

BRAUN-BLANQUET, J. Fitossociologia. Bases para el estudio de las comunidades vegetales. Madrid: Editora Blume, 1979.

BERTRAND, G. Paysage et géographie physique globale: esquisse méthodologique. Revue géographique des Pyrénées et Sud-Ouest, Toulouse, v. 39, n. 3, p. 249-272, 1968.

BERTRAND, G. Paisagem e geografia física global: esboço metodológico. Caderno de Ciências da Terra, n. 13, p. 1-27, 1971.

BERTRAND, G. Paisagem e geografia física global: um esboço metodológico. Revista R. RAEGA. Curitiba, n. 8, p. 141-152, 2004.

BONI, P. V. Estudo biogeográfico em cordilheiras sob pressão da pecuária no Pantanal do Abobral. 2020. Dissertação (Mestrado em Geografia) - Universidade Federal de Mato Grosso do Sul, Três Lagoas.

CAMPOS, M. C. C. Relações solo-paisagem: conceitos, evolução e aplicações. Ambiência, Guarapuava, vol. 8, n. 3, p. 963-982, set./dez., 2012.

CARDOSO, E. L. et al. Relação entre solos e unidades da paisagem no ecossistema Pantanal. Pesquisa Agropecuária Brasileira, Brasília, vol. 51, n. 9, p. 1231-1240, set., 2016.

CARDOSO, E. L.; FERNANDES, A. H. B. M.; FERNANDES, F. A. Análise de Solos: Finalidade e Procedimentos de Amostragem. Comunicado Técnico 79. Embrapa: Corumbá. 2009. 
CARVALHO FILHO, A. de; CARDOSO, E.L.; NAIME, U.J.; MOTTA, P.E.F. da; OLIVEIRA, H. de; BRANCO, O.D.; SANTOS, R.D. dos. Solos como fator de diferenciação fitofisionômica na subregião da Nhecolândia - Pantanal Mato-Grossense. In: SIMPÓSIO SOBRE RECURSOS NATURAIS E SÓCIO-ECONÔMICOS DO PANTANAL, 3., 2000, Corumbá. Anais... Corumbá: Embrapa Pantanal, 2000. p.59-60.

COREL CORPORATION. CoreIDRAW Graphics Suite 2020 (Versão Gratuita). Disponível em: $<$ https://www.coreldraw.com/br/free-trials/> Acesso em: 20 jan. 2021.

CUNHA, N. G.; POTT, A.; GONÇALVES, A. R. Solos calcimórficos da sub-região do Abobral, Pantanal Mato-Grossense. Corumbá: Embrapa Pantanal, 1985.

DIAS, J. A. A Análise Sedimentar e os Conhecimentos dos Sistemas Marinhos. Faro: Universidade do Algarve, 2004.FELFILI, M. F.; CARVALHO, F. A.; HAIDAR, R. F. Manual para o monitoramento de parcelas permanentes nos biomas Cerrado e Pantanal. Brasília: Universidade de Brasília, 2005. 55p.

FERREIRA, F. F. et al. Efeito de um gradiente de umidade na riqueza de espécies associadas a Attalea phalerata (Mart.) Palmae. In: CAMARGO, G. et al. Ecología do Pantanal: curso de campo. Campo Grande: Oeste, 2001. p. 40-43.

FIGUEIRÓ, A. Biogeografia: dinâmicas e transformações da natureza. São Paulo: Oficina de texto, 2015.

FRANCO, M. S. M.; PINHEIRO, R. Geomorfologia. In: RADAMBRASIL, série Geomorfologia. Folha SE. 21 Corumbá e parte da Folha SE. 20, vol. 27. Rio de Janei5ro: Ministério de Minas e Energia, Secretaria Geral. Projeto RADAMBRASIL, 1982, p. 161-224.

FURLAN, S. A.; SOUZA, R. M.; LIMA, E. R. V.; SOUZA, B. I. Biogeografia: reflexões sobre temas e conceitos. Revista da Anpege. São Gonçalo, RJ. 2016.

HOBOware for PC and Mac, Version 3.7.21. Onset Computer Corporation. ®1995-2021. Disponível gratuitamente em <https://www.onsetcomp.com/hoboware-free-download/> Acesso em: 22 dez 2020

IBGE - Instituto Brasileiro de Geografia e Estatística. Censo Agropecuário 2006. Disponível em:<https://www.ibge.gov.br/estatisticas/economicas/agricultura-e-pecuaria/2006-np-censoagropecuario/9827-censo-agropecuario.html?=\&t=0-que-e> Acesso em: 06 dez. 2020.

IBGE - Instituto Brasileiro de Geografia e Estatística. Censo Agropecuário 2017. Disponível em:<https://www.ibge.gov.br/estatisticas/economicas/agricultura-e-pecuaria/2017-np-censoagropecuario/9827-censo-agropecuario.html?=\&t=0-que-e> Acesso em: 06 dez. 2020.

KERBAUY. G. B., Fisiologia Vegetal. 2. ed. Guanabara Koogan, 2008.

LIMA. L. Espécies Invasoras. Galileu. Rio de Janeiro, n.145, p.45- 56, ago. 2003.

MARTONNE, E. Abrégé de Geographie Physiqu. 3. ed. Paris: Armand Colin. 1932. 355 págs.

MEDEIROS, J. C.; ALBUQUERQUE, J. A.; MAFRA, A. L.; ROSA, J. D.; GATIBONI, L. C. Relação cálcio:magnésio do corretivo da acidez do solo na nutrição e no desenvolvimento inicial de plantas de milho em um Cambissolo Húmico Álico. Semina: Ciências Agrárias, Londrina, v. 29, n. 4, p. 799806, out./dez. 2008.

MENDONÇA, F.; DANI-OLIVEIRA, I. M. Climatologia. Noções Básicas e Climas do Brasil. São Paulo: Oficina de Texto, 2007.

MIOTO, C. L.; PARANHOS FILHO, A. C.; ALBREZ, E. A. Contribuição à caracterização das subregiões do Pantanal. Entre-Lugar, Dourados, vol. 3, n. 6, p 165-180, 2012.

MORAES NETO, S. P. Acidez, alcalinidade e efeitos da calagem no solo. Planaltina, DF: Embrapa Cerrados, 2009. Disponível em:

https://www.infoteca.cnptia.embrapa.br/infoteca/bitstream/doc/657358/1/art005.pdf Acesso em: 08 maio 2020.

NEGRELLI, R. R. B. Estrutura populacional e potencial de regeneração de Attalea phalerata Mart. Ex Spreng. (Acuri). Ciências Florestais, Santa Maria, v. 23, n. 4, p. 727-734, 2013. 
NUNES, D. P. Avaliação da Nutrição de Arroz Irrigado Cultivado em Solos com Diferentes Texturas e seu Efeito na Sanidade e Produtividade de Grãos. 86 f. Fundação Universidade Federal do Tocantins, Dissertação (Mestre em Melhoramento Genético Vegetal), 2016.

PADOVANI, C. R.; CRUZ, L. L.; PADOVANI, S. L. A. G. Desmatamento do Pantanal Brasileiro para o ano de 2000. In: SIMPÓSIO SOBRE RECURSOS NATURAIS E SÓCIO-ECONÔMICOS DO PANTANAL, 4., 2004, Corumbá. Anais... Corumbá: Embrapa Pantanal, 2004.

PASSOS, M. M. Biogeografia e paisagem. Maringá: Universidade Estadual de Maringá, 1988.

QUEIROZ, R. I. P. Geoambientes e solos no Pantanal do Abobral, Mato Grosso do Sul, Brasil. 2018. 82 f. Dissertação (Mestrado em Qualidade Ambiental) Universidade Federal de Uberlândia, Uberlândia, 2018.

RADAMBRASIL. Geologia da folha SE 21 Corumbá. Geologia, geomorfologia, pedologia, vegetação e uso potencial da Terra. Levantamento de Recursos Naturais. RADAMBRASIL, Ministério das Minas Energia, 27, 1982.

RAVAGLIA, A. G.; SANTOS, S. A.; PELLEGRIN, L. A.; RODELA, L. G.; SILVA, L. C. F. Classificação Preliminar das Paisagens da Sub-região do Abobral, Pantanal, Usando Imagens de Satélite. Corumbá: Embrapa Pantanal, 2010.

ROSSI, C. Q. Matéria orgânica do solo e fósforo orgânico em cronossequência de cana-deaçúcar cultivada no cerrado. Tese de doutorado. Universidade Federal Rural do Rio de Janeiro. 2013.

SAMUKA, M. Z.; SILVA, M. H. S. A técnica das pirâmides de vegetação aplicada a análise de unidades florestais de vegetação arbórea densa no Pantanal do Abobral. In: PEREZ FILHO, A.; AMORIM, R. R. (org). Os desafios da Geografia Física na Fronteira do Conhecimento. Campinas: Instituto de Geociências - UNICAMP, 2017.

SÁNCHEZ, R. O. Las unidades geomorficas del pantanal y sus connotaciones biopedoclimaticas. (Estudo de Desenvolvimento Integrado da Bacia do Alto Paraguai). Brasília: EDIBAP/SAS, 1977.

SEMAC - Secretaria de Estado de Meio Ambiente, Cidades, Planejamento, Ciência e Tecnologia de Mato Grosso do Sul-. Portaria IMASUL 098-2008. Disponível em: $<w w w . s e r v i c o s . m s . g o v . b r / i m a s u l d o w n l o a d s / P l a n o s d e M a n e j o / p l a n o m a n e j o P E P R N . p d f>$. Acesso em: 08 jan. 2019.

SEPÚLVEDA, J. J. O. Conservação, Grau de Ameaça e Monitoramento Participativo da Biodiversidade por Meio do Turismo da Subregião do Abobral no Sul do Pantanal Brasileiro. 2016. 90 f. Dissertação (Mestrado em Meio Ambiente e Desenvolvimento Regional Sustentável). Universidade Para O Desenvolvimento do Estado e da Região do Pantanal (Uniderp), Campo Grande. 2016.

SILVA, J.S.V.; ABDON, M.M. Delimitação do Pantanal Brasileiro e suas sub-regiões. Pesquisa Agropecuária Brasileira, Brasília, vol. 33, n. especial, p. 1703-1711, 1998.

SILVA, M. H. S. Análise da Paisagem do Pantanal da Nhecolândia: Estudo de Caso de Lagoas Salitradas Sob a Perspectiva do Modelo GTP (Geossistema, Território e Paisagem). 2012. 279 f. Tese (Doutorado em Geografia) - Universidade Estadual Paulista (Unesp), Presidente Prudente. 2012.

SILVA, M. H. S. Pirâmides de Vegetação como Estratégia Metodológica para Análise Biogeográfica. In: DIAS, L. S. e GUIMARÃES, R. B. Biogeografia: conceitos, metodologias e práticas. Editora ANAP, Tupã/SP. 2016.

SILVA, M. H. S.; GRADELLA, F. S.; DECCO, H. F. Estudo comparativo das variações microclimáticas em distintas unidades da paisagem no Pantanal do Abobral em Mato Grosso do Sul. Revista Eletrônica da Associação dos Geógrafos Brasileiros - Seção Três Lagoas/MS, n. 26, p. 186-199. 2017.

SOARES, A. F.; SILVA, J. S. V.; FERRARI, D. L. Solos da paisagem do Pantanal brasileiro adequação para o atual sistema de classificação. In: SIMPÓSIO DE GEOTECNOLOGIAS NO PANTANAL, 1. 2006. Anais... Campo Grande, MS. Campinas: Embrapa Informática Agropecuária; São José dos Campos: INPE, 2006. p. 275-284.

$\begin{array}{llllll}\text { Caminhos de Geografia } & \text { Uberlândia-MG } & \text { v. 23, n. } 85 & \text { fev./2022 } & \text { p. 20-41 } & \text { Página } 40\end{array}$


SOARES, A. P., SOARES, P. C.; ASSINE, M. L. Areais e lagoas do Pantanal, Brasil: herança paleoclimática. Revista Brasileira de Geociências. v. 33, n. 2, p. 211-224, 2003.

SOKOLOWSKI, H. G. S et al.; Dinâmica Microclimática e suas conexões com os sistemas atmosféricos nas unidades de paisagem, Pantanal da Nhecolândia, MS: Caso do dia 22 a 28 de julho de 2014. Fórum Ambiental da Alta Paulista, Volume 11, n5, ANAP, Tupã-SP, 2015.

SOUZA, C. A; LANI, J. L; SOUSA, J. B. Origem e evolução do Pantanal Mato-grossense. In: SIMPÓSIO NACIONAL DE GEOMORFOLOGIA, 6., 2006. Anais ... Disponível em:

$<$ http://www.labogef.iesa.ufg.br/links/sinageo/aut/articles/132.pdf>. Acesso em: 3 jun. 2019.

SUGUIO, K. Introdução a sedimentologia. São Paulo: Editora da USP, 1973.

TAIZ. L.; ZEIGER, E.; MOLLER, I; MURPHY, A. Fisiologia e desenvolvimento vegetal. 6.ed. Porto Alegre: Artmed, 2017. 888 p.

TOMAS, W. M.; MOURÃO, G.; CAMPOS, Z.; SALIS, S. M.; SANTOS, S.A. Intervenções Humanas na Paisagem e nos Habitats do Pantanal. Corumbá: Embrapa Pantanal, 2009.

UNESCO. $O$ patrimônio mundial no Brasil. Brasília. Caixa Econômica Federal, 2000.

Recebido em: 11/09/2020

Aceito para publicação em: 25/01/2021 